\title{
Protein cage nanostructure as drug delivery system: magnifying glass on apoferritin
}

\section{Daniela Belletti, Francesca Pederzoli, Flavio Forni, Maria Angela Vandelli, Giovanni Tosi \& Barbara Ruozi}

To cite this article: Daniela Belletti, Francesca Pederzoli, Flavio Forni, Maria Angela Vandelli, Giovanni Tosi \& Barbara Ruozi (2016): Protein cage nanostructure as drug delivery system: magnifying glass on apoferritin, Expert Opinion on Drug Delivery, DOI: $\underline{10.1080 / 17425247.2017 .1243528}$

To link to this article: http://dx.doi.org/10.1080/17425247.2017.1243528

Accepted author version posted online: 30

Sep 2016.

Submit your article to this journal $\pi$

View related articles $\sqsubset$

View Crossmark data $₫$ 
Publisher: Taylor \& Francis

Journal: Expert Opinion on Drug Delivery

DOI: $10.1080 / 17425247.2017 .1243528$

\title{
Protein cage nanostructure as drug delivery system: magnifying glass on apoferritin
}

Daniela Belletti ${ }^{1}$, Francesca Pederzoli ${ }^{1}$, Flavio Forni ${ }^{1}$, Maria Angela Vandelli ${ }^{1}$, Giovanni Tosi $^{1 *}$, Barbara Ruozi ${ }^{1}$

${ }^{1}$ Laboratory of Nanomedicine, Te.Far.T.I., Department of Life Sciences, University of Modena and Reggio Emilia, Via Campi 103, 41124, Modena, Italy

*Corresponding author:

Giovanni Tosi, Tel: +39.059.2058563; Email: gtosi@unimore.it

\begin{abstract}
Introduction: New frontiers in nanomedicine are moving towards the research of new biomaterials. Apoferritin (APO), is a uniform regular self-assemblies nano-sized protein with excellent biocompatibility and a unique structure that affords it the ability to stabilize small active molecules in its inner core.
\end{abstract}

Areas covered: APO can be loaded by applying a passive process (mainly used for ions and metals) or by a unique formulative approach based on disassemby/reassembly process. In this 
article, we aim to organize the experimental evidence provided by a number of studies on the loading, release and targeting. Attention is initially focused on the most investigated antineoplastic drug and contrast agents up to the most recent application in gene therapy.

Expert opinion: Various preclinical studies have demonstrated that APO improved the potency and selectivity of some chemotherapeutics. However, in order to translate the use of APO into therapy, some issues must be solved, especially regarding the reproducibility of the loading protocol used, the optimization of nanocarrier characterization, detailed understanding of the final structure of loaded APO, and the real mechanism and timing of drug release.

Keywords: Apoferritin, Chemotherapeutics, Disassembly/reassembly, Nano-cage, Passive loading, Structural characterization

\section{Article highlights box}

- APO is a self-assembled molecule highly conserved in mammalian and with a high biocompatibility.

- APO offers the possibility to guest within its inner core drugs of low molecular weight and positiyely charged. The mechanism of drug loading can follow passive absorption/penetration processes or $\mathrm{pH}$-dependent disassembly/reassembly protocols.

- Only a limited number of drugs (mainly chemotherapeutics containing metals or anthracycline) are successfully loaded into APO, showing promising results in preclinical animal models.

- APO is characterized by long lifetime and innate affinity for tumor cells due to its ability to bind human TtR1 receptor, over-expressed on cells in rapid proliferation.

- Modern biotechnological approaches lead to the production of recombinant protein able to link molecules (active and/or targeting agents) directly to the protein structure, 
thus improving the efficacy of loaded APO and expanding its applicability to different field of therapy. 


\section{Introduction}

The production and the development of drug delivery systems (DDS), completely biocompatible, atoxic, and biodegradable is a challenging issue. Thus, modern nanomedicine focused its interest on alternative biomaterials as proteins.

The nature offers different types of multimeric proteins able to self-assemble in protein shell surrounding a hollow interior cavity with shapes and structures within nanometer scale [1]. From a biological point of view, protein cages play numerous functions as the storage, protection and delivery of viral genomes, metal storage, and protein refolding.

Their applicability as DDS depends on the technological formulatiye aspects as handy, reproducible, scalable methods of formulation and drug encapsulation as well as on the efficient purification process.

In this contest, advanced competences in the field of biotechnology help a sustainable largescale production of proteins using cell factories, making this technology highly desirable and economically advantageous for different technological applications.

One of the most investigated classes of proteins applicable in drug delivery is the ferritin superfamily and particularly Apoferritin (APO) [2,3]. In this review, starting from the analyses of the structure of APO, we focus on the mechanism of drug loading in APO cage and the versatility of this protein as DDS in therapy.

\section{Ferritin superfamily}

Ferritins are a superfamily of proteins which is highly conserved in eukaryotic organisms and ubiquity diffused in humans and other mammals, plants, fungi, and bacteria [4].

The role of ferritin is fundamental for life; it is the first protein involved in iron storage and seizure, thus playing a role of reservoir for metabolic iron. 
The crystal structures of many Ferritins were deeply characterized since the beginning of 1990s by the combination of Transmission Electron Microscopy (TEM), small angle X ray scattering (SAXS) and proteomic techniques [4-7].

In spite of large variations in amino acid sequences from bacteria to humans, ferritins essentially show the same architecture. Focusing on mammalians, the ferritin's protein cage (450-500 $\mathrm{kDa})$ is composed of 24 polypeptide subunits, with different molecular weights [8] and with specific functions [9]. Heavy $(\mathrm{H})$ units (molecular weight of $21 \mathrm{KDa}$ ) play a major role in iron oxidation while light $(\mathrm{L})$ units (molecular of $19 \mathrm{KDa}$ ) are more involved in the efficient nucleation and mineralization of iron. Of note, $\mathrm{H}$ and $\mathrm{L}$ subunits are highly homologous, and they can form a spherical unit in any proportion [10].

The ratio between the two types of chain in Ferritin is different with respect to the species and the tissues [11 as in relation to physiological state, as the amount of $\mathrm{H}$ chains increases in inflammation and other pathological conditions in response to cytokine stimuli $[12,13]$. Moreover, as reported in the text below (Chapter 4.1), differences in the type of receptorbinding are present between $\mathrm{H} / \mathrm{L}$ Ferritin/Apoferritin as only H-Ferritin or H-Apoferritin are able to bind TtR1 receptors whereas L-Ferritin and L-Apoferritin bind SCARA5 receptors.

The subunits self-assemble to form a spherical cage with outer diameter of $12 \mathrm{~nm}$, a $2 \mathrm{~nm}$ thick protein shell and a internal cavity with diameter of $8 \mathrm{~nm}$. Overall, the protein molecular mass is $450 \mathrm{KD}$ a and it is able to store up to $4500 \mathrm{Fe}(\mathrm{III})$ atoms $[4,14]$.

The inner and the outer space are connected by pores size of about $0.3-0.5 \mathrm{~nm}[15,16]: 8$ of these pores defined " 3 -fold channels" are hydrophilic and they lead iron to diffuse into (and out of) the core; the other 4 pores defined " 4 fold channels" are hydrophobic and their function is still unclear $[17,18]$.

Finally, it is worth to consider that during the protein reassemblation, amino acidic content differs from inner to outer cavities. Generally, ferritin have a preponderance of acidic over 
basic residues with high level of non apolar groups thus the isoelettric point is generally in the range 4.5-5.5).

The ferritin surface resulted highly reactive and some substances can bind to the apoferritin surface through hydrogen bonding (non-ionic molecules) or electrostatic interactions (ionic molecules) [19].

\section{From Ferritin to APO the applicability as DDS}

As above described, from a physiologic point of view, ferritin can be described as Fe (III) reservoir. Aiming to exploit APO as DDS, the inner cavity should be free and able to accommodate the cargo, thus the resident iron has to be removed from the cavities. Demineralization of ferritin occurred by reductive dissolution and subsequent chelation of Fe(II) producing APO [20,21] which maintains the same features of Ferritin in terms of inner and outer structures.

The octahedral scaffold of APO displays typical hydrophilic and hydrophobic channels connecting inner cavities to the external surface and which are proposed as the route for inward and outward of metals and other molecules (therapeutic agents such as imaging agents) [22].

This mechanism of accumulation into the core [23] is named "passive loading". Unless initially investigated, being a rapid and scalable loading process, it results often less efficient and not able to stabilize therapeutic molecules with large molecular weights, which result prevalently adsorbed on the surface. Therefore, deeper studies on strategies of improving drug loading with active loading, or at least by means of strong modification in the protocols of Ferritin assembly were conducted over the last 10 years. In this contest, a number of studies mostly aimed to elucidate the permeation mechanism of organic molecules into APO and the impact of chemico-physical characteristics on drug loading efficiency. As example, NMR relaxation techniques were employed to investigate the diffusion of molecules devoid of net 
charge and with 18-7500 Da MW (i.e. water, DMSO, glucose, maltose, maltotriose, maltoteraose, maltopentaose and polyethylene glycol) into the protein cavity [24]. The authors demonstrated that the channel structure is sufficiently flexible to allow the penetration of molecules even larger than their own size (3-4 $\AA$ ), but with maximum dimensions typical of the maltose (Mw: $342 \mathrm{Da}$, corresponding to a diameter of $13 \AA$ ) [24].

Electron paramagnetic resonance spectroscopy analysis were employed to study the diffusion of small and differently charged nitroxide organic probes (7-9 $\AA$ of diameter) to the central cavity of the ferritin, showing that the diffusion inside the protein is not purely passive (not only linked to the concentration gradient between the inside and outside of the protein) but also strictly dependent on their respective charge and the polarity. Only positively charged probes penetrate into the protein through the 3-fold channels, while not polar molecules bind the hydrophobic regions of the protein only on in its outer surface $[25,26]$.

Aiming to extend the number of applications, the research moves through alternative methods to load drug and investigate the dynamic of disassembly and reassembly of the protein nanocage.

Thanks to a large number of intra- and inter-subunit salt bridges and hydrogen bonds, the APO structure is known for its stability: i) over heating condition (up to $85^{\circ} \mathrm{C}$ ) [27]; ii) amongst a wide $\mathrm{pH}$ range (3.40-10) [28]; iii) in presence of high ionic concentrations; iv) in presence of high concentrations of denaturing agents [29,30].

Even if highly stable to chemical and physical denaturants, the APO architecture can be disassembled in response to $\mathrm{pH}$ variation and then restored, almost completely, by returning the $\mathrm{pH}$ back to the "physiological" conditions ( $\mathrm{pH}$ 7.4). A number of hypotheses to describe the structural changes during disassembly and reassembly of protein were proposed.

One of the first theories hypothesized that APO remains stable in the range of $\mathrm{pH}$ 2.8-10.6. On the contrary, at lower $\mathrm{pH}(1.6-2.8)$ or higher $\mathrm{pH}$ (10.6-13.0), a drastic reduction of $\mathrm{MW}$, which can be related to the presence disassembled subunits, occurs [31]. 
A still open question is related to the exact $\mathrm{pH}$ at which protein starts its disassembling process. Some authors suggest that a progressive process [32] takes place; this event consists of cleavage of non-covalent bonds as a consequence of a conformational rearrangement of the protein [30]. Along with the decrease of $\mathrm{pH}$, the outer surface of APO becomes positively charged (due to the protonation of the carboxylic groups of amino acid), leading to the progressive loosing of subunits forming holes in the spherical structure which switch from the inside to the outside [31]. By combining SAXS data and 3D structural reconstruction, it was shown that more the $\mathrm{pH}$ decreases and more the holes become numerous and larger, finally generating rodlike structures at $\mathrm{pH} 2$ [28].

In these conditions, APO is completely disassembled into its subunits and allows to molecules/drug present in solution to interact with the chains.

To lead sub units to reassemble and to form the native conformation, it is pivotal to restore the native electrostatic potential, thus, the solution needs to be buffered to the $\mathrm{pH}$ to "physiological" values [33]. Within this reassembly process, drug loading takes places as the drug molecules are entrapped into the spherical structure (Fig.1).

In turns, aiming to expand the drug loading possibilities, some authors chose to move to different $\mathrm{pH}$ values, especially in the basic range. Notwithstanding less conformational data are available regarding the basic dissociation of APO, it was supposed starting over $\mathrm{pH} 10.6$ and caused by the de-protonation and re-arrangement of tyrosine residues. A high level of attention should be posed on monitoring $\mathrm{pH}$ values, as continuing the basification over $\mathrm{pH}$ 12.4 lead to an irreversible alkaline hydrolysis of peptide bonds [34], disabling any possible recovery of native conformation [31].

\section{Pharmacokinetics of APO as DSS}

After parenteral administration the pharmacokinetic profile of APO was investigated in tumor bearing model. Drug-loaded APO are rapidly distributed into the bloodstream reaching small 
capillaries. These protein DDS do not cross normal vessels, as only molecule smaller than 3 $\mathrm{nm}$ are allowed to pass the endothelial cells by means of transcellular route [35], but their low diameter (less than $20 \mathrm{~nm}$ ) is sufficient to avoid macrophages capture. This drastically reduces a-specific uptake by the reticular endothelial system (RES) [36] and assures to keep the protein longer into bloodstream circulation.

Membranes of endothelial cells of blood vessels expose receptors that recognize APO and control both iron uptake and transferrin passage from vessel to tissues. $\mathrm{H}$ and $\mathrm{L}$ subunits show some differences in receptor affinity, as the $\mathrm{H}$ subunit specifically binds the receptor of transferrin (TfR1) with a wild distribution in human cells while $L$ subunit binds to the Scavenger Receptor Class A Member 5 (SCARA5) firstly localized in macrophages, retina and hepatocytes [10,37].

As evident, the protein composition is pivotal to define the APO destiny and, at the same time, the well-known over-expression of TfR1 in many cancer cells (about 100-fold respect to normal tissue) [38,39] guarantees an intrinsic site-specific targeting potential of APO nanocage for tumor.

Moreover, tumor produces much more growing factors, leading to the presence of blood capillaries which tend to be disorganized, oversized, and leaky. As consequence, a large number of drug molecules and small structure (as APO) can be effectively driven to cancer tissue and stick onto pathological cells.

Also the mechanism of APO interaction with cells and especially with tumor cells was investigated, in vitro using CACO-2 cells, showing that APO exploits clathrin-dependent endocytosis [40], accumulates into endosomes and releases the protein cargo into cytoplasm as a consequence of acidification of the compartment, which is responsible of the progressive dissociation of APO [41].

\subsection{APO in drug delivery, the tumor case}


A number of anticancer drugs suffer poor selectivity for neoplastic cells leading to doselimiting side effects, which compromise clinical outcomes.

Unfortunately, only limited number of drugs were investigated as well-defined drug properties are needed: i) controlled molecular weight (typically in the range 300-600 Da); ii) positive charged at physiological $\mathrm{pH}$ thus able to produce electrostatic interaction with the inner negatively charged protein cavity. In this view, DOXO possesses good properties $(\mathrm{MW}=544 \mathrm{Da}$; and $\mathrm{pKa}=7.34$ (phenol); 8.46 (amine); 9.46 (est). Different operative conditions were screened in order to optimize its loading into APO, in particular the effect of the buffer, the ionic strength and the protein concentration during the dissociation process.

During the last decades, the major interest was dedicated to the investigation of the development of loaded APO as DDS for anticancer molecules (Table 1). Among current used chemioterapeutics with low bioavability and selectivity some of them display chemicophysical characteristics (low MW and cationic charge at physiologic $\mathrm{pH}$ ) suitable for stabilization into APO. Moreover, thanks to the innate affinity for tumor cells the encapsulation is supposed to enhance the cell interaction with the tumor cells thus reducing the side and not-target accumulation and side effects. Considering this particular cancer targeting, H-ferritin should be used in order to produce cages able to really and successfully target cancer human cells. Notably, mouse models of cancer should not be taken into consideration, due to the presence of different receptors.

Gefinitinib, an epidermal grown factor (EGFR) receptor tyrosine kinase inhibitor (MW 447 Da), was passively loaded in APO. Drug resulted probably distributed in the inner and outer part of the protein cage (totally 10 molecules for each APO), thus the release starts at physiological $\mathrm{pH}$ and maximizes at $\mathrm{pH} 2$ in correspondence with the protein disassembly. 
Authors demonstrated that Gefinitinib/APO induced cytotoxicity in breast cancer cell lines over-expressing both TtR1 and HER-2 receptors whit a profile comparable to that of free drug [42].

A strong effort in the research was focused on strategies to force structured molecules to stably enter the APO core. In some particular cases (i.e. doxorubicin and mainly Gd), for molecules with appropriate MWs, some authors proposed a pre-complexation of the molecule with a metal in order to use the natural affinity of metal for the inner core of APO as driving force to maximize the passage through the 3 -fold channels.

Doxorubicin (DOXO), a wide spectrum anticancer antibiotic with affinity for different metals was previously pre-complexed with $\mathrm{Cu}(\mathrm{II})$, and efficiently loaded by simple incubation in APO systems $(\mathrm{Cu} / \mathrm{DOXO} / \mathrm{APO})[43,44]$. These strategy increases the drug loading efficiency in APO compared by simple DOXO/APO (30:100 DOXO:APO w/w ratio in presence of $\mathrm{Cu}$ respect to 8:100 DOXO:APO w/w ratio in absence of metal) [45]. $\mathrm{Cu} / \mathrm{DOXO} / \mathrm{APO}$ keeps both the dimension and the morphology of $\mathrm{DOXO} / \mathrm{APO}$ and APO alone and no aggregates were observed. The release of the drug in physiological conditions, showed a typical biphasic profile characterized by an initial bust effect (about $80 \%$ of drug) and absence of drug release over $48 \mathrm{~h}$. These data could indicate that the metal-drug complex is mostly adsorbed on the surface of protein. Notwithstanding technological data seems to suggest only a limited ability to protect DOXO, in vitro and in vivo tests on tumor models showed that DOXO/APO nanocages, targeted to integrin $\operatorname{Rv} \beta 3$ (a tumor angiogenesis biomarker) by RGD peptide anchored on APO surface, displayed a better therapeutic profile, resulting in a longer circulation half-life, higher tumor uptake, better tumor growth inhibition, and less cardiotoxicity than free DOXO [45].

A second strategy proposed to force the drug into the protein core consists of disassemblyreassembly process. The natural metal binding site present in the inner core of APO can be used as driving force to stabilize some metal-containing compounds. In this contest, platinum 
based anticancer drugs could be efficiently encapsulated into APO after dissociation at $\mathrm{pH} 2$ and reconstitution at physiologic $\mathrm{pH}$.

Cisplatin and carboplatin were loaded with the aim to reduce the systemic toxicity and high tumor resistance [46]. Through ICP-MS analysis authors demonstrated that about 2 and 5 molecules of cisplatin and carboplatin respectively became part of the protein structure, eyen if not clear evidences about the rate between internalization and absorption were reported. In a further study, these data were corroborated by a deeper characterization of platinum loaded APO (oxaliplatinum) and evaluating the effect on a cancer cell line overexpressing transferrin receptor. Data highlighted the low toxicity of APO on cancer cells and the rapid decreased of cellular viability as a consequence of internalization of loaded protein, thus suggesting the potentiality of APO to overcome the mechanism of resistance typical of this type of metal based anticancer drug [35].

As alternative, cisplatin was stabilized into APO after dissociation at more handy and "stable" formulative conditions, as weak alkaline $\mathrm{pH}$ [47]. Once tested on cancer cells cisplatin loaded into APO showed the ability to induce cytotoxicity through the same apoptosis pathway of free drug. Even if it is not clearly proved the exact localization of the drug within the APO, the evidence that APO slows down the biological response at short time respect to free drug, suggests that the protein plays an important role in controlling the drug release over the time. Disassembly-reassembly process was also applied to load drugs in APO without precomplexation with metal. To date, only limited number of drugs were investigated as welldefined drug properties are needed: i) controlled molecular weight (typically in the range 300$600 \mathrm{Da})$; ii) positive charged at physiological $\mathrm{pH}$ thus able to produce electrostatic interaction with the inner negatively charged protein cavity. In this view, DOXO possesses good properties $(\mathrm{MW}=544 \mathrm{Da}$; and $\mathrm{pKa}=7.34$ (phenol); 8.46 (amine); 9.46 (est). Different operative conditions were screened in order to optimize its loading into APO, in particular the 
effect of the buffer, the ionic strength and the protein concentration during the dissociation process.

Interestingly, the use of glycine-acetate buffer ( $\mathrm{pH} 2.5)$ is the one more efficacious approach in disassembling APO without any effect related to the initial protein concentration [48].

Since only $\mathrm{H}$ chain showed affinity for cancer cells through the binding with transferrin receptor, by means of an elegant combination of chemical engineering and fermentation technology, different types of mammalian ferritin variants were formulated by selfassembling by only $\mathrm{H}$ subunits (H-APO) [49]. Thus, H-APO was loaded with DOXO following both the previously reported acidic [50,51] or basic dissociation protocols [52]. The complex DOXO loaded H-APO (DOXO/H-APO), tested in vitro, was compared in term of efficacy with free DOXO and with clinical approved liposome loaded DOXO formulation (Doxil@).

The "innate" targeting ability of the protein cage was confirmed as DOXO/H-APO showed better ability to mediate efficient and rapid interactions with cancer cells than the other control formulations [50,51]. Some conflicting data derived from in vitro distribution studies; $\mathrm{DOXO} / \mathrm{H}-\mathrm{APO}$ rapidly entered in a colon cancer cell line accumulating in lysosomes where DOXO is gradually released and subsequently translocated into nucleus [52]. Differently, in a liver carcinoma cellular line, DOXO/H-APO accumulated rapidly into nucleus through a specific interaction of $\mathrm{H}$ subunit with receptor exposed on nuclear membrane. Accordingly, DOXO intercalates DNA causing higher and more rapid cytotoxicity in cancer cells respect to controls (DOXO or Doxil) [50-51].

We could speculate on the different biological response and mechanism of cellular accumulation as consequence of multiple aspects, especially relating to the sensibility of tumor type and to the effect of the architecture and surface proprieties of loaded APO formulated applying different protocols. As evident, more efforts are needed to completely characterize these new entities. 
To go further, DOXO/H-APO, obtained by means of basic dissociation protocol, was in vivo tested aiming to investigate pharmacokinetics profile and toxicity in mice bearing tumor (colon cancer cells). Namely, DOXO loaded into APO showed 10 fold higher AUC and tumor accumulation with respect to free drug and Doxil and reduced the drug concentration in healthy tissues (muscle, lung, kidney, spleen and most importantly heart). In addition, DOXO/H-APO led to a significant reduction in tumor growth two-fold higher than Doxil@ [52].

The protocols for encapsulation of DOXO are now used as a template. Recently atropine and carbachol, two molecules active on muscarinic receptors, involved in the development of pancreatic tumor, was loaded into APO cage. All studied molecules show similar MW $($ carbachol $=183 \mathrm{Da}$; atropine $=290 \mathrm{Da})$ and $\mathrm{pKa}$ (carbachol $=12.5$; atropine $=4.5)$, suggesting loading efficiencies similar to DOXO case. Authors described an efficient accumulation both in vitro and in vivo at the tumor site, a partial suppression of tumor development and a reduction of toxicity if compared with the treatment with free drugs [53].

To ameliorate the affinity of APO for cancer cells, some authors proposed the surface modification by the insertion of target moieties as antibodies or peptides.

APO has a fair versatility regarding chemical reactivity: in fact, a variety of chemical groups, e.g. primary amines, carboxylates, and thiols present on the external and internal surface, can be linked either genetically $[29,45]$ and/or chemically [54,55]. Interestingly, after surface modification, APO diameter generally increased and the surface proprieties change (zetapotential, hydrophilicity). As a consequence, the cellular interaction appeared to be more driven by the presence of ligands exposed onto the surface than by the "innate" tumor affinity of APO.

That way, a complex of daunorubicin (DAUNO) with negatively charged polypeptide PLLA (poly-L-aspartic acid) $[24,56]$ was incorporated into APO after a partial disassembling at $\mathrm{pH} 5$ and reassembly at physiological $\mathrm{pH}$. To target solid tumor cells, the surface of APO was 
engineered (by means of NHS/EDC protocol) with hyaluronic acid able to specifically bind CD44. The efficacy of this engineered nanocage was in vitro tested on a lung cancer cells overexpressing CD44 and a control cell line, not expressing any antigen. Modified nanocages were safe and tolerable for both cell lines, but it was clearly demonstrated that the cellular uptake was strongly driven by the binding with the cellular antigen. Briefly, DAUNO/APO accumulated only in CD44 positive cell line and both the cellular uptake and cytotoxicity were sensible to the pre-incubation with free antigen (which means inhibiting the cell specific binding) [56].

In a second example, APO loaded with cisplatin proposed by Xing and collaborators [35] was conjugated through a NHS-PEG-Mal cross-linker with an antibody selective to a proteoglycan expressed on the surface of melanoma cells (CSPG4). The new modified vectors showed a significant increase in both their molar mass and diameters ( $33 \mathrm{~nm} \mathrm{Vs} 13 \mathrm{~nm}$ of native APO). In vitro studies confirmed that modified APO specifically bound melanoma cells expressing CSPG4(+), but not CSPG4(-) breast cancer cells and, accordingly, in vivo study showed a delayed tumor growth in model mice of melanoma. On the contrary, the tumor size of breast tumor, which does not over-expressed the specific antigen, was only marginally affected [57]. Recently APO was proposed as non-viral system to stabilize and protect small interfering RNA (siRNA). SiRNA are characterized by high MW and negatively charges, features that hampered a stable internalization into the protein core. Taking advantage of the protein recombinant technology, APO was modified aiming to orderly expose cationic peptides on its surface. Thus, protamine-derived peptides were inserted as moieties able to complex and capture siRNA; besides, APO was also modified with penetrating peptides to enhance the target delivery to tumor cells.

The experiments clearly highlighted that after modified-APO/siRNA complexation, the targeting peptides exposed on the protein surface drove the complex-cellular interaction and 
siRNA accumulated into the cell cytoplasm, thus opening to a great potential for further applications of APO in gene therapy applied to cancer treatment (Fig. 2; Table 1) [58].

\subsection{Application of APO in diagnosis}

Imaging agents are among those compounds that can be successfully loaded into the interior cavity of APO protein (Table 2).

Magnetic Resonance Imaging (MRI) is a non-invasive imaging method for tumor diagnosis, however most of the diagnostic agents suffers from a lack of selectivity, low proton relaxivity and higher toxicity after administration [59].

APO could act as dual-functional tools allowing both the use of protein shell to target tumors and the ability in loading probes within the internal core to image tumors.

Gadolinium (GD) is one of the most used contrast agent in clinical and experimental settings; thus a number of authors proposed the formulation of water suspended APO-GD formulation with high NMR longitudinal relaxivity similar to clinically approved GD-chelates. [59-62]. The technology employed in order to stabilize this contrast agent, described for the first time more than 10 years ago, was based on a well-described acidic protocol (dissociation at $\mathrm{pH} 2$ ) and the use of a neutral chelates (GD-HPDO3A) [59].

To improve tumor targeting, the surface of APO/GD-HPDO3A was engineered via streptavidin-biotin technology with an antibody directed to neural cell adhesion molecules (NCAM), overexpressed during the angiogenesis in endothelial cells. After in vivo administration, this new contrast agent was stable for few hours with a relaxation efficiency 5fold higher with respect to the free probe, showing an increase in selectivity for tumor vessels [62].

In a more recent work, in order to maximize the loading efficiency, GD-HPDO3A was replaced with a positively charged GD-Me2-DO2A. With the aim to assure a stable insertion 
into the cavity, the process was modified by adding GD complex during the acidification stage (at pH 4). Finally, the surface decoration of GD loaded APO with dextran lead to the accumulation of APO in transplanted tumor region in mice due to the exploitation of EPR effect [60].

Also Mn ions could be used as contrast agent in MRI. Through the stabilization into APO it has been demonstrated the improving in relaxitivities $[63,64]$. These non invasive imaging tools were applied as MRI sensor for different kinds of tumor. Taking advantage of the reduced expression of SCARA5 (ine of the APO cellular receptor) into hepatoma cells respect to health hepatocites, Geninatti and co-workers demonstrated the possibility to discriminate between tumor lesion and monitor the hepatic tumor progression with a sensitivity similar to commercial probe (Gd-BOTA) [65]. A similar structure was also developed for the early diagnoses and imaging of melanoma cells. The increased melanin production in cancer cells correspond to an increased reduction of Mn (III) to Mn (II) (by the oxidation of L-DOPA to melanin) thus producing an high relaxivities and contrast during MRI investigation [66].

Also iron is another optimal contrast agent for MRI. Autologous ferritins have been successfully investigated as a MRI contrast agent. One of the first example reported described the use of a cationized ferritins for MR imaging of kidneys (obtained after coupling with N, N dimethyl-1,3 propanediamine (DMPA) that after iv administration accumulated in the kidneys because the glomerular basement membrane is negatively charged [67]. More recently ferritin was investigated as MRI contrast agent in neurodegenerative disorders because of the documented alterated iron metabolism in many neurodegeneration (particularly Alzheimer's disease and Huntington's disease [68]. As example of this application in vivo experiments in mice demonstrated that it is possible to increase the iron expression (thus the MRI signal) in nerve cells of mice after transfection of nerve cells using lentiviral and adenovirus vectors expressing transferrin [69] (for a complete review on this point see ref. 70). Unless some application reported, generally endogenous ferritin shows low relativity index if compared to 
synthetic iron oxide nanoparticles [71]. Human recombinant H-APO offers the possibility to act as suitable platform for synthesis and encapsulation of magnetite nanoparticles (Fe3O4), leading to the obtainment of optimal contrast agent for MRI for tumor diagnoses. Starting from the first studies on APO formulation containing an iron core in the form of magnetite (Fe3O4) [72-73], the research moved to the surface engineering aiming to achieve improved tumor selectivity. That way, magnetoferritin was modified using ligand able to target tumor markers such as RGD-4C that can specifically target tumor angiogenesis via binding to integrin molecules on vascular endothelium [74] melanocyte-stimulating hormone (MSH), or epidermal growth factor (EGF) [75,76]. Besides the surface modification to increase the tumor detection, other imaging modalities, such as fluorescence imaging and positron emission tomography (PET) were investigated [77].

Recently, APO loaded with Cu64 and Cy5 was modified with RGD4C peptide anchored to the ferritin surface by conjugation with the surface amines. This structure was able to target the tumor, by means of RGD-integrin interaction and the enhanced permeability and retention (EPR) effect [78].

\subsection{Application of Apo as theranostic tool}

The growing knowledge and advances in nanomedicine drive the recent research in formulating systems containing simultaneously both drugs and imaging agents. The combination of therapy and diagnoses in a single drug delivery system is now emerging as theranostic approach.

This strategy can find applications for various different purposes, as to monitor the biodistribution and the target site accumulation of nanomedicines, to visualize and quantify drug release, and to assess the efficacy of the therapeutic treatment $[79,80]$. 
The design of a theranostic nanosystems could be obtained by following different protocols in terms of drug loading processes and insertion of the diagnostic agents (Table 3).

The DOXO/APO systems characterized by a natural affinity for tumor were largely studied and recently were modified onto their surface with magnetic particles by means of streptavidin-biotin technology. This approach preserved the natural loading ability of APO and it avoided any possible incompatibility between drug and diagnostic agent. Authors demonstrated that modified DOXO/APO was sensible to the application of a magnetic field, thus enabling also a $\mathrm{pH}$-dependent release of the drug and opening the pave to a possible in vivo application in the treatment and diagnoses of tumors [54].

More recently a DOXO/APO complex was specifically designed as theranostic agent for prostate cancer. Briefly, the surface was double engineered with an antibody direct to anti PMSA (prostate specific membrane antigen) and with gold nanoparticles. The complex coverage of protein seems to protect the cargo from undesired premature release in the bloodstream; moreover, once tested in vitro, this new carrier assured a nice selectivity for prostate cancer cells preserving healthy cells from the drug toxicity [81].

A different approach is based on a contemporary loading into the inner cavity of the protein of diagnostic and drug molecules.

The cytostatic drug 5-fluorouracil (5-FU), being characterized by a low molecular weight, rapidly leak from the APO cavity; thus to better stabilize the encapsulation, [82] proposed a simultaneous loading with gold nanoparticles (AU-NPs, 3nm of diameter) known for their optical and photothermal proprieties. 5-FU enters trough hydrophilic protein pores and once into the protein core binds AU-NPs via electrostatic interaction. This strategy avoided the leaking of 5-FU under physiological condition and promotes the drug release only after accumulation of APO inside the intracellular acidic compartments. In a very complete and worthy in vitro study, the complex was demonstrated to be able to increase the cytotoxic 
profile of the drug in different tumor cell lines, pointing out the wide applicability of the new therapeutic entities.

Similarly, curcumin, a multi-target drug with potent antioxidant proprieties, was loaded into APO simultaneously with GD through an acidic dissociation protocol, obtaining about 9 and 0.4 molecules of curcumin and GD respectively loaded into APO, with a consequent increase in APO diameter of about $66 \%$ (from 12 to $19 \mathrm{~nm}$ ). In presence of curcumin, the gadolinium complex conserves its typical relaxivities and rapidly accumulates into liver (passive targeting). Based on this peculiar distribution, authors proposed the vector as a theranostic agent for a variety of liver diseases (Fig. 3) [83].

\subsection{A look over cancer, other possible applications of Apo as DDS}

The versatility of APO was recently exploited for the potentiality of antigen presentation onto the surface and immune stimulation in vaccines formulation.

Generally, vaccines for immunization standard schedules are stably prepared and protocols of production are well standardized, but, for rapidly mutating-pathogens (as the influenza virus), it is necessary to prepare new complex vaccines on an annual basis to avoid possible circumvention of the immune system by mutated pathogen.

The subunits of APO offer different regions tolerant to peptide insertion; these regions were therefore modified to obtain proteins expressing exogenous components that are able to conserve the ability to re-organize into spherical nanocage [84].

Following this approach, APO was synthetized in a controlled manner in terms of quantity and location of substituent. By selecting the site for protein insertion, it is possible to expose the antigens on the outer surface [77-78] or both inner and outer [85]. From a technological point of view, new vaccines were characterized by using PCS ant TEM to prove spherical shape and presence of the exposed antigen. 
To evaluate the real efficacy of these new entities in comparison with licensed inactivated vaccines, different in vitro and in vivo tests were performed. Generally, after administration in mice, those APO exposing the antigen protein onto the outer surface induced a higher CD8+ and CD4+ T cell proliferative response and therefore their transformation in functional $\mathrm{T}$ cells [86].

In view of expanding the applicability of APO in therapy, Zhang and coworkers exploited the applicability of APO in enzyme stabilization. Considering the large MW and steric hindrance of the molecule to be loaded, the internalization into the protein core appeared difficult, thus the enzyme glucose oxidase (GOx) (chosen as model enzyme) was immobilized onto the protein surface. Authors demonstrated that GOx linked on the surface through a biotinstreptavidin approach retained most of its activity up to two weeks and resulted stable to exposition to high temperatures (up to $50^{\circ} \mathrm{C}$ ). This study presents a novel approach to enhance stability and activity of enzyme with promising application in different therapy but also in biological assay [87].

Finally, in a recent paper aiming to explore the applicability of APO in brain disease therapy, H-Apo was tested on a cerebellar organotypic culture demonstrating high affinity for astrocyte cell and a rapid and massive accumulation into nuclei [50].

\section{Table 3: APO utilization in therapy}

\section{Conclusion}

APO, featured by high stability, special and reproductive structure, auto-assembly ability and biocompatibility, is certainly one of the most investigated and interesting structures proposed in the modern scenario of nanomedicines.

From the beginning of its history (less than 15 years) as material for drug delivery, its applicability was investigated within the field of cancer medicine due to its natural affinity for iron receptor, largely distributed on cells in rapid division. Unfortunately, based on its specific 
conformation and small internal spaces, only a limited number of chemotherapeutics (mainly belonging to anthracycline family as daunomycin and doxorubicin or contrast agent for tumor diagnoses and resulted suitable for successful loading into APO cage. Aiming to broaden the field of APO application, two main technological innovations were proposed: i) the engineering the protein surface by means of linkage of molecules able to drive the destiny of the protein cage; ii) the use of protein reactivity to link the drug or the active molecules directly on the surface. That way, APO became object of investigations in other fields of nanomedicine as gene therapy, immunology or liver pathology.

\section{Expert opinion}

Despite extensive promises, much work is needed before clinical translation of APO. As example, analyzing literature data, even if interestingly biological data are reported supporting the efficacy of this DDS, the study of the architecture and the structure of loaded APO are still at early stages. This situation, which represents the major limitation is translatability of APO to become DDS, is principally caused by unclear protocols for APO formulation and un-clear chemico-physical, morphological and technological characterization and it frequently generates conflicting outputs.

Points to be focused with major attention are related to the nature and narrow size of APO complex and to the evidence that the analytical technique commonly used to characterize synthetic DDS as liposomes or nanoparticles (TEM, AFM, SEM, PCS, DSC etc) are unable to completely demonstrate structure, architecture and, in particular, the presence of drug or ligands onto APO surface.

These data relating to chemico-physical and morphological characterization of APO formulations are essential to determine the fate and the perspective of any DDS, as any change in surface proprieties, even small differences in chains re-arrangements could strongly 
affect the interaction with serum proteins, recognition by immune systems, impacting on the cage biocompatibility and also on the ability to transport drug to the site of action.

Currently, within their experimental plan only few studies are considering the evaluation of the effective recovery of conformation after the loading and disassembly process. Generally, when investigated, this issue on the final APO structure is approached by applying far-UV circular dichroism (CD). CD permits to evaluate the presence and the distribution of helical structures into the new protein entities. Despite these data are surely reliable, the results are not representative of the real integrity of protein after loading or disassembly/reassembly process.

To overcome these limits, X-ray diffraction characterization, even if expensive and sometimes difficult to be rendered, could be considered as the best choice for the characterization of protein structural conformation. As an example, a study performed by SAXS technique showed clearly that protein reassembly process couldn't be totally complete after strong acidification; under $\mathrm{pH} 2.4$ the protein completely loses its spherical structure that cannot be recovered. The $\mathrm{pH}$ limit for pseudo-reversible restoration of the quaternary structure was set at $2.66[28]$.

One of the best example of an almost complete study of APO formulation is represented by a recent work [88] in which cisplatin loaded APO were formulated by applying the same method proposed by Ji and coworkers [47] and were submitted to a deep structural characterization by means of X-ray analyses and elaboration of data. By comparing loaded and unloaded samples with native APO, the authors confirmed that the overall structure (shape, polarity/hydrophobicity, volume and electrostatic potential of the surface) remained stable after the formulation process. Notably, comparing native and cisplatin-loaded APO, the most relevant structural differences were detected close to the site of drug loading and in particular at the His 132, found to be the metal-binding site. 
This work represents an important keystone for further investigations aiming to confirm the maintenance of the structural integrity of the protein, in particular regarding the encapsulation of non-metal drug with large MW.

Furthermore, another point to be investigated aiming to improve the chances of translatability of APO as drug delivery systems is related to the drug release and in particular to the changes in morphology and architecture of APO cage during and after the release of the drugs. To our knowledge, poor information are given on this topic which obviously impacts on several technological key-features of APO drug delivery systems, as the efficiency in drug release, the possibility of governing/modifying the drug release and also the biocompatibility of APO after the release of the drugs. These aspects are still far from an overall evaluation and therefore need to be considered with a major interest.

As final consideration, it seems almost clear that the improvement and the consecration of potentialities of APO application in different fields of drug targeting must be obtained by an extensive collaboration among researchers in the field of technology, chemical-physical characterization and physicians. 


\section{Funding}

This work was partially financed by FAR UNIMORE grants (MA Vandelli and GTosi) by University of Modena and Reggio Emilia.

\section{Declaration of interest}

The authors have no other relevant affiliations or financial involvement with any organization or entity with a financial interest in or financial conflict with the subject matter or materials discussed in the manuscript apart from those disclosed.

\section{References}

\section{Papers of special note have been highlighted as either of interest $(\bullet)$ or of considerable} interest $(\bullet \bullet)$ to readers.

[1] Ma-Ham,A, Wu H, Wang J, et al. Apo-based nanomedicine platform for drug delivery: equilibrium binding study of daunomycin with DNA. Journal of Materials Chemistry 2011; 21: $8700-08$

[2] Yildiz I, Shukla S, Steinmetz NF. Applications of viral nanoparticles in medicine.

Biochem J 2011;22:901-08

[3] Uchida M, Terashima M, Cunningham $\mathrm{CH}$, et al. A human ferritin iron oxide nanocomposite magnetic resonance contrast agent. Magn Reson Med 2008;60:1073-81

[4] Harrison PM, Arosio P. The ferritins: molecular properties, iron storage function and cellular regulation. Biochim Biophys Acta 1996;1275:161-203

- One of the first study describing the structure and function of APO

[5] Harrison PM. The structure of Apo: Molecular size, shape and symmetry from X-ray data. J Mol Biol 1963; 6:404-22

[6] Rice DW, Ford GC, White JL, et al. The spatial structure of horse spleen Apo. Adv Inorg Biochem 1983;5:39-50 
[7] Ha Y, Shi D, Small GW, et al. Crystal structure of bullfrog M ferritin at 2.8 A resolution: analysis of subunit interactions and the binuclear metal center. J Biol Inorg Chem 1999;4:24356

[8] Arosio A, Adelman G, Drysdale JW. On Ferritin Heterogeneity. J Biol Chem 1978; $253: 4451-58$

[9] Lawson DM, Artymiuk PJ, Yewdall SJ, et al. Solving the structure of human $\mathrm{H}$ ferritin by genetically engineering intermolecular crystal contacts. Nature $1991 ; 349: 541-4$

[10] Li L, Fang CJ, Ryan JC, et al. Binding and uptake of H-ferritin are mediated by human transferrin receptor-1. Proc Natl Acad Sci U S A 2010;107: 3505-10.

[11] Levi S, Salfeld J, Franceschinelli F et al. Expression and structural and functional properties of human ferritin L-chain from Escherichia coli. Biochemistry 1989; 28:5179-84. [12] Massover WH. Ultrastructure of ferritin and Apo: A review. Micron 1993;24:389-437. [13] Douglas T, Allen M, Young M. Self-assembling Protein Cage Sytems and Applications in Nanotechnology. Polyamides and Complex Proteinaceous Materials 2005 DOI: $10.1002 / 3527600035 . b p 018015$

[14] Ford GC, Harrison PM, Rice DW et al. Ferritin: design and formation of an iron-storage molecule. Philos Trans R Soc Lond B Biol Sci 1984;304: 551-65

[15] Zhao G. Phytoferritin and its implications for human health and nutrition. .

BiochimBiophys Acta 2010;1800:815-23

[16] Takahashi T, Kuyucak S. Functional properties of threefold and fourfold channels in ferritin deduced from electrostatic calculations. Biophysical Journal 2003;84:2256-63.

[17] Bou-Abdallah F. The iron redox and hydrolysis chemistry of the ferritins. Biochim. Biophys Acta 2010;1800:719-31

[18] Theil EC. Ferritin protein nanocages use ion channels, catalytic sites, and nucleation channels to manage iron/oxygen chemistry. Curr Opin Chem Biol 2011;15:304-11. 
[19] Liu F, Du BJ, Chai Z et al. Binding properties of apoferritin to nicotinamide and calcium.

Eur Food Res Technol 2012; 235: 893-99

[20] Ponka P, Richardson DR. Can ferritin provide iron for hemoglobin synthesis? Blood $1997 ; 89: 2611-3$

[21] Gelvan D, Fibach E, Meyron-Holtz EG et al. Ferritin uptake by human erythroid precursors is a regulated iron uptake pathway. Blood 1996;88:3200-07

[22] Maham A, Tang Z, Wu H, et al. Protein-based nanomedicine platforms for drug delivery. Small 2009;5:1706-21

•- An interesting review summarizing the versatility of protein as drug delivery systems [23] Linder MC. Mobilization of Stored Iron in Mammals. A Review. Nutrients 2013; 5: $4022-50$

[24] Yang D, Nagayama K. Permeation of small molecules into the cavity of ferritin as revealed by proton nuclear magnetic resonance relaxation. Biochem J 1995; 307:253-56

[25] Yang X, Chasteen ND. Molecular diffusion into horse spleen ferritin: a nitroxide radical spin probe study. Biophysical Journal 1996;71:1587-95

[26] Yang X, Arosio P, Chasteen ND. Molecular diffusion into ferritin: pathways, temperature dependence, incubation time, and concentration effects. Biophysical Journal 2000;78:.2049-59

[27] Sengonul M, Ruzicka J, Attygalle AB, et al. Surface Modification of Protein Nanocontainers and Their Self-Directing Character in Polymer Blends. Polymer (Guildf) $2007 ; 48: 3632-40$

[28] Kim M, Rho Y, Jin KS, et al. pH-Dependent Structures of Ferritin and Apo in Solution: Disassembly and Reassembly. Biomacromolecules 2011; 12:1629-40

[29] Arosio P, Ingrassia, R, Cavadini, et al. A Family of Molecules for Iron Storage, Antioxidation and More. Biochim Biophys Acta 2009; 1790: 589-99 
[30] Gerl M, Jaenicke R. Assembly of Apo from horse spleen: comparison of the protein in its native and reassembled state. Biol Chem Hoppe Seyler 1987; 368:387-96

[31] Crichton RR, Bryce CFA. Subunit interactions in horse spleen Apo. Dissociation by extremes of pH. Biochemical Journal 1973;133:289-99

[32] Imai N, Arata Y, Fujiwara S. 1H NMR study of dissociation and re-association of apoferritin and ferritin. Bulletin of the Chemical Society of Japan 1981;54:1243-44

[33] Chen L, Bai G, Yang R, et al. Encapsulation of $\beta$-carotene within ferritin nanocages greatly increases its water-solubility and thermal stability. Food Chem 2014; 149:30712 [34] Xing R, Wang X, Zhang C, et al. Characterization and cellular uptake of platinum anticancer drugs encapsulated in apoferritin. J Inorg Biochem 2009;103:1039-44 [35] Azzi S, Hebda JK, Gavard J, et al. Vascular Permeability and Drug Delivery in Cancers. Front Oncol 2013;3:211

[36] Molino NM, Wang SW. Caged protein nanoparticles for drug delivery. Curr Opin Biotechnol 2014;28:75-82.

[37] Huang J, Zheng DL, Qin FS et al. Genetic and epigenetic silencing of SCARA5 may contribute to human hepatocellular carcinoma by activating FAK signaling. J Clin Invest. $2010 ; 120: 223-41$

[38] Daniels TR, Delgado T, Rodriguez JA, et al. The transferrin receptor part I: Biology and targeting with cytotoxic antibodies for the treatment of cancer. Clin Immunol 2006;121:14458.

[39] Bretscher MS, Thomson JN. Distribution of ferritin receptors and coated pits on giant HeLa cells. EMBO J 1983; 2: 599-603

[40] Oh N, Park JH. Endocytosis and exocytosis of nanoparticles in mammalian cells. Int J Nanomedicine 2014; 9:51-63

[41] Liu X, Wei W, Yuan Q. Apo ceO2 nano truffle that has excellent redox enzyme activity. Chem Commun (Camb) 2012;48:3155-7 
[42] Kuruppu AI, Zhang L, Collins H, et al. An Apo based drug delivery system for the tyrosine kinase inhibitor Gefitinib. Adv Healthc Mater 2015;4:2816-21

[43] Feng M, Yang Y, He P, et al, Spectroscopic studies of copper(II) and iron(II) complexes of adriamycin. Spectrochim Acta A Mol Biomol Spectrosc 2000;56:581-7

[44] May PM, Williams GK, Williams DR. Speciation studies of adriamycin, quelamycin and their metal complexes. InorgChim A-bioinorg 1980;46:221-228

[45] Zhen Z, Tang W, Chen H, et al. RGD-Modified Apo Nanoparticles for Efficient Drug Delivery to Tumors. ACS Nano 2013;7:4830-37

[46] Yang Z, Wang X, Diao H, et al. Encapsulation of platinum anticancer drugs by apoferritin. Chem Commun (Camb) 2007 Sep 7;(33):3453-5

[47] Ji XT, Huang L, Huang HQ. Construction of nanometer cisplatin core-ferritin (NCC-F) and proteomic analysis of gastric cancer cell Apoptosis induced with cisplatin released from the NCC-F. J Proteomics 2012;75:3145-57

[48] Kilic MA, Ozlu E, Calis S. A novel protein-based anticancer drug encapsulatingnanosphere: Apo-doxorubicin complex. J Biomed Nanotechnol 2012; 8:508-14 [49] Grace JE, Van Eden ME, Aust SD. Production of recombinant human Apo heteromers. Arch Biochem Biophys 2000;384:116-22

[50] Zhang L, Li L, Di Penta A, et al. H-Chain Ferritin: A Natural Nuclei Targeting and Bioactive Delivery Nanovector. Adv Healthc Mater 2015;4:1305-10

- An interesting paper describing the intracellular localization of loaded APO.

[51] Bellini M, Mazzucchelli S, Galbiati E, et al. Protein nanocages for self-triggered nuclear delivery of DNA-targeted chemotherapeutics in Cancer Cells. J Control Release 2014;

$196: 184-96$

[52] Liang M, Fan K, Zhou M, et al. H-ferritin-nanocaged doxorubicin nanoparticles specifically target and kill tumors with a single-dose injection. Proc Natl Acad Sci U S A. $2014 ; 111: 14900-5$ 
- A very interesting paper describing the efficacy of recombinant protein as effective vehicle for doxorubicin.

[53] Lei Y, Hamada Y, Lia J, et al. Targeted tumor delivery and controlled release of neuronal drugs with ferritin nanoparticles to regulate pancreatic cancer progression. J Control Release $2016 ; 28 ; 232: 131-42$.

[54] Blazkova I, Nguyen HV, Dostalova S, et al. Apoferritin modified magnetic particles as doxorubicin carriers for anticancer drug delivery. Int J Mol Sci 2013; 14:13391-402

[55] Liu, G., Wang, J., Lea, S.A., et al. Bioassay Labels Based on Apoferritin Nanovehicles. ChemBioChem 2006;9:1315-19

[56] Luo Y, Wang X, Du D, et al. Hyaluronic acid-conjugated apoferritin nanocages for lung cancer targeted drug delivery. Biomater Sci 2015;3:1386-94

[57] Falvo E, Tremante E, Fraioli R, et al, Antibody-drug conjugates: targeting melanoma with cisplatin encapsulated in protein-cage nanoparticles based on human ferritin. Nanoscale $2013 ; 5: 12278-85$

[58] Lee EJ, Lee SJ, Kang YS, et al, Engineered proteinticles for targeted delivery of siRNA to cancer cells. Adv Funct Mater2015;25:1279-86

[59] Aime S, Cabella C, Colombatto S, et al. Insights into the use of paramagnetic Gd(III) complexes in MR-molecular imaging investigations. J Magn Reson Imaging 2002;16:394-406 [60] Makino A, Harada H, Okada T, et al. Effective encapsulation of a new cationic gadolinium chelate into Apo and its evaluation as an MRI contrast agent. Nanomedicine $2011 ; 7: 638-46$

[61] Sánchez P, Valero E, Gálvez N, et al. MRI relaxation properties of water-soluble Apoencapsulated gadolinium oxide-hydroxide nanoparticles. Dalton Trans 2009;7:800-4 [62] Geninatti Crich S, Bussolati B, Tei L, et al. Magnetic resonance visualization of tumor angiogenesis by targeting neural cell adhesion molecules with the highly sensitive gadolinium-loaded apoferritin probe. Cancer Res 2006;66:9196-201 
[63] Kálmán FK, Geninatti-Crich S, Aime S. Reduction/dissolution of a beta-MnOOH nanophase in the ferritin cavity to yield a highly sensitive, biologically compatible magnetic resonance imaging agent. Angew Chem Int Ed Engl 2010;49:612-5

[64] Meldrum FC, Douglas T, Levi S et al. Reconstitution of manganese oxide cores in horse spleen and recombinant ferritins. Inorg Biochem. 1995; 58:59-68

[65] Geninatti Crich S, Cutrin JC, Lanzardo S et al. Mn-loaded apoferritin: a highly sensitive MRI imaging probe for the detection and characterization of hepatocarcinoma lesions in a transgenic mouse model. Contrast Media Mol Imaging 2012; 7:281-8

[66] Szabó I, Crich SG, Alberti Dzabó I et al. Mn loaded apoferritin as an MRI sensor of melanin formation in melanoma cells. Chem Commun (Camb). 2012; 48:2436-8 [67] Danon D, Goldstein L, Marikovsky Y et al., Use of cationized ferritin as a label of negative charges on cell surfaces. J Ultrastruct Res 1972; 38:500-10

[68] Bartzokis G, Tishler TA. MRI evaluation of basal ganglia ferritin iron and neurotoxicity in Alzheimer's and Huntingon's disease. Cell Mol Biol (Noisy-le-grand) 2000; 46:821-33 [69] He D, Marles-Wright J Ferritin family proteins and their use in bionanotechnology. N Biotechnol 2015;32:651-7

[70] Zhen Z, Tang W, Todd T et al. Ferritins as Nanoplatforms for Imaging and Drug Delivery. Expert Opin Drug Deliv. 2014; 11:1913-22.

[71] Gossuin Y, Muller RN, Gillis P, et al. Relaxivities of human liver and spleen ferritin. Magn Reson Imaging 2005; 23:1001-4

[72] Uchida M, Klem MT, Allen P et al. Biological Containers: Protein Cages as Multifunctional Nanoplatforms. Advanced Materials 2007;19:1025-42

[73] Uchida M, Terashima M, Cunningham $\mathrm{CH}$, et al. A human ferritin iron oxide nanocomposite magnetic resonance contrast agent. Magn Reson Med 2008;60:1073-81 
[74] Kitagawa T, Kosuge H, Uchida M, et al. RGD-conjugated human ferritin nanoparticles for imaging vascular inflammation and angiogenesis in experimental carotid and aortic disease. Mol Imaging Biol 2012;14:315-24

[75] Vannucci L, Falvo E, Fornara M, et al. Selective targeting of melanoma by PEG-masked protein-based multifunctional nanoparticles. Int J Nanomedicine 2012;7:1489-509

[76] Li X, Qiu LH, Zhu P, et al., Epidermal growth factor-ferritin h-chain protein nanoparticles for tumor active targeting. Small 2012;8:2505-14

[77] Fan K, Gao L, Yan X. Human ferritin for tumor detection and therapy. Wiley Interdiscip Rev Nanomed Nanobiotechnol2013;5:287-98

-• An interesting review summarizing the versatility of APO in imaging.

[78] Lin X, Xie J, Niu G, et al. Chimeric ferritin nanocages for multiple function loading and multimodal imaging. Nano Lett 2011;11:814-19

[79] Lammers T, Kiessling G, Hennick WE, et al. Nanotheranostics and image-guided drug delivery: current concepts and future directions. Nanomedicine 2008;3:137-40

[80] Janib SM, Moses AS, MacKay JA. Imaging and drug delivery using theranostic nanoparticles. Adv Drug Deliv Rey 2010;62:1052-63

[81] Dostalova S, Cerna T, Hynek D, et al. Site-Directed Conjugation of Antibodies to Apoferritin Nanocarrier for Targeted Drug Delivery to Prostate Cancer Cells. ACS Appl Mater Interfaces 2016; 8:14430-41

- A very complete and well done study describing the formulation of an engineered APO structure applicable in theranostic.

[82] Liu XY, Wei W, Huang SJ et al. Bio-inspired protein-gold nanoconstruct with corevoid-shell structure: beyond a chemo drug carrier. J Mat Chem B 2013;1:3136-43

[83] Cutrin JC, Crich SG, Burghelea, et al. Curcumin/Gd Loaded Apo: A Novel “Theranostic" Agent To Prevent Hepatocellular Damage in Toxic Induced Acute Hepatitis. Mol Pharm 2013;10:2079-85 
[84] Kang HJ, Kang YJ, Lee YM, et al. Developing an antibody-binding protein cage as a molecular recognition drug modular nanoplatform. Biomaterials 2012; 33:5423-30

[85] Han JA, Kang YJ, Shin C. Ferritin protein cage nanoparticles as versatile antigen delivery nanoplatforms for dendritic cell (DC)-based vaccine development. Nanomedicine $2014 ; 10: 561-9$

[86] Kanekiyo M, Wei C-J, Yassine HM, et al. Self-assembling influenza nanoparticle vaccines elicit broadly neutralizing H1N1 antibodies. Nature 2013; 499:102-106

-• An excellent paper exploiting the applicability of APO for vaccine development.

[87] Zhang Y, Tang Z, Wang J, et al. Apoferritin nanoparticle: a novel and biocompatible carrier for enzyme immobilization with enhanced activity and stability. J Mater Chem $2011 ; 21: 17468-75$

[88] Pontillo N, Pane F, Messori L, et al. Cisplatin encapsulation within a ferritin nanocage: a high-resolution crystallographic study. Chem Commun (Camb). 2016; 52:4136-9.

-• The first complete chemical physical and crystallographic characterization of APO loaded with a metal drug. 
Fig 1: Graphical representation of the mechanisms for drug loading into APO.

Fig 1: Graphical representation of the mechanisms for drug loading into APO. A) APO formed by $H / L$ subunit can be passively loaded by simple incubation with a drug solution. In function of the MW of the drug, different loading dynamics could be supposed. B) APO structure can be broken down to subunits at low or high $\mathrm{pH}$, incubated with drug and finally the structure can be reassembled once the $\mathrm{pH}$ is tuned back to neutral lead the drug molecules to be trapped into the protein inner core.
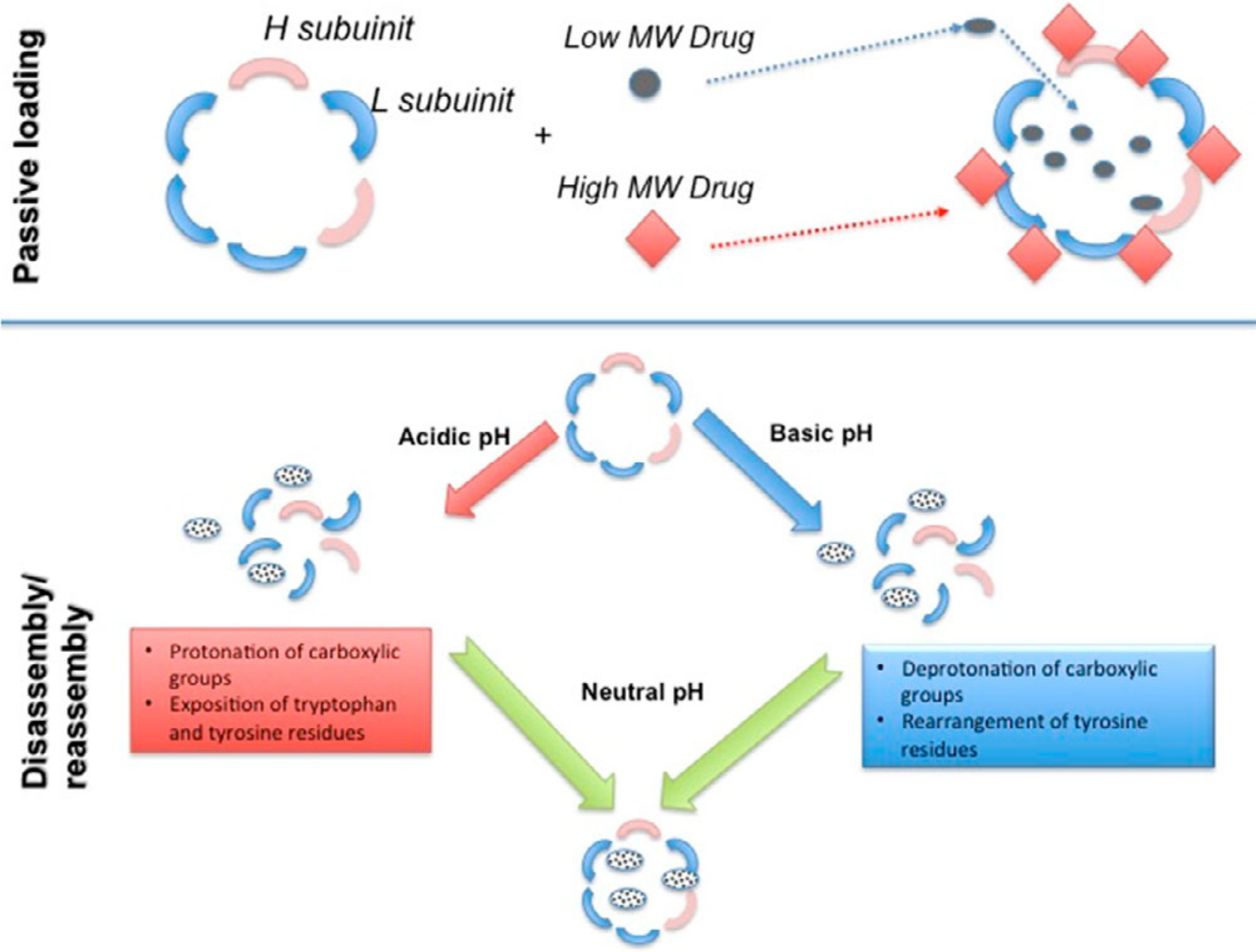


\section{Fig.2: Schematic illustration of APO application in therapy.}

Fig.2: Schematic illustration of APO application in therapy. A) Different kind of active molecules were loaded of chemically linked on the surface of APO. These systems were applied for drug delivery and targeting, imaging and theranostic applications. B) Due to the intrinsic affinity for tumor cells loaded APO was mainly applied in cancer treatment, however recently this technology is applied in other field of research (immunotherapy, brain disease, enzyme replacement therapy).

a)

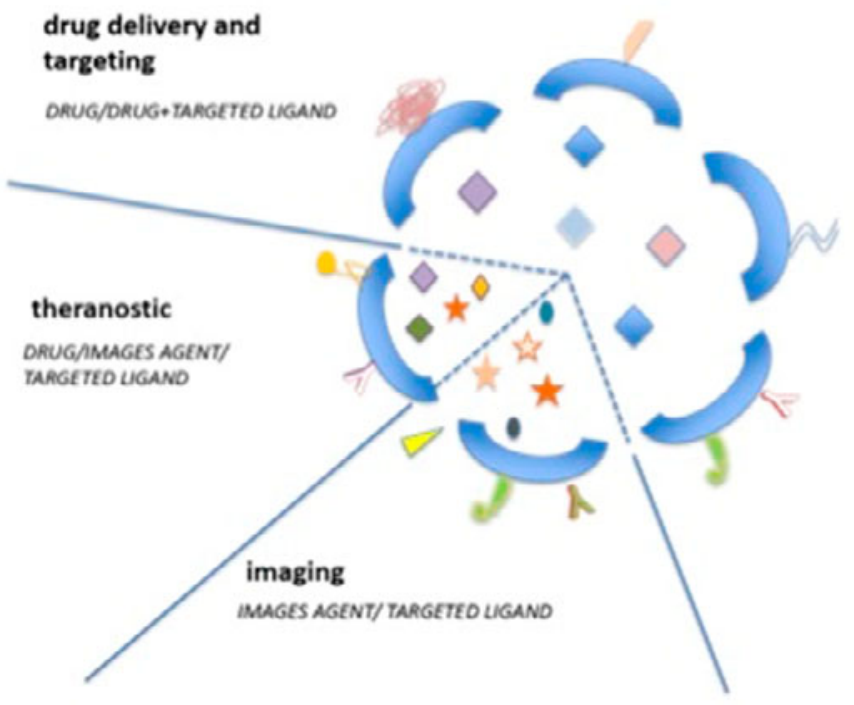

uGeNo:

(1) ooxo

1) Daunompich

- Caselatin

- Carboglatin

oraliplatin

60

COMe2002A

Gd mecosa

nGD

Dextran

Antigen peptides
- Curcumin

- s.ru

A sinna

- gacu

- Fejor

y mabvicsaga

$Y$ mab wn NCAM

Y MabV WSMA

aUNA

de slucose ovidare

b) 


\section{Fig.3. Theranostic Applications:}

Figure 3. Theranostic Applications: a) co-encapulation of active molecules (i.e. anticancer 5-FU, anti-oxidant curcumin) and contract agents (i.e. gold nanoparticles, Gd) into APO cage; b) encapsulation of anticancer molecule (i.e. doxorubicin) and surface engineering with multiple ligands for targeting and detection

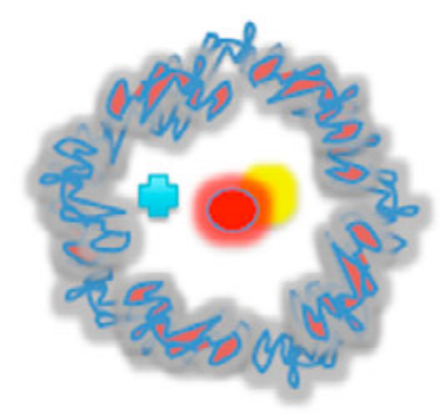

Drug (i.e. 5-FU, Curcumin)

Contrast Agent (i.e. Gold Nanoparticles, Gd)

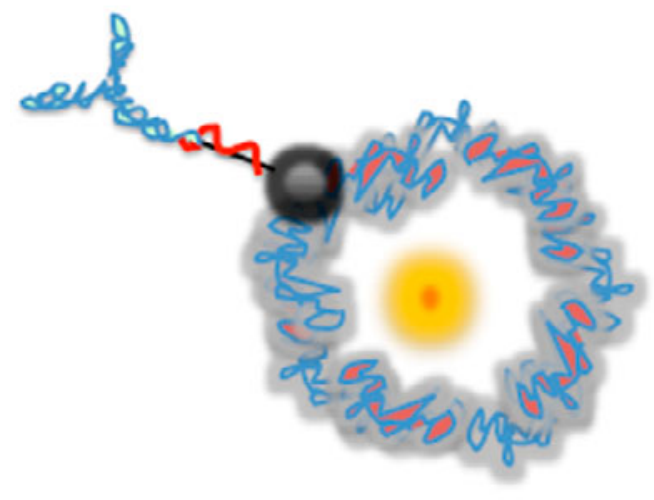

Doxorubicin (anticancer/easy traceable)

Multiple Targeting Agent

-magnetic nanoparticles

1 -targeting peptide 


\begin{tabular}{|c|c|c|c|c|c|c|c|c|}
\hline \multirow[b]{2}{*}{ Drug } & \multirow[b]{2}{*}{$\begin{array}{c}\text { Method of } \\
\text { encapsulatio } \\
\mathbf{n}\end{array}$} & \multirow[b]{2}{*}{$\begin{array}{c}\text { Surface } \\
\text { ligand }\end{array}$} & \multirow[b]{2}{*}{$\begin{array}{c}\text { Source of } \\
\text { APO }\end{array}$} & \multicolumn{5}{|c|}{ Outcomes/Short comings } \\
\hline & & & & $\begin{array}{l}\text { 1.Chemico- } \\
\text { physical and } \\
\text { technological } \\
\text { studies }\end{array}$ & $\begin{array}{l}\text { 2. In vitro } \\
\text { (VT)/in vivo } \\
\text { (VV) model } \\
\text { Test adopted }\end{array}$ & $\begin{array}{l}\text { Structural/technologica } \\
\text { I end point }\end{array}$ & $\begin{array}{l}\text { Biological end } \\
\text { points }\end{array}$ & Ref \\
\hline Gefitinib & $\begin{array}{l}\text { Passive } \\
\text { loading at } \mathrm{pH} \\
7.2\end{array}$ & & $\begin{array}{l}\text { Recombinan } \\
\mathrm{t}\end{array}$ & $\begin{array}{l}\text { TEM, UV-VIS, } \\
\text { MALDI, gel } \\
\text { electrophoreses }\end{array}$ & $\begin{array}{l}\text { VT: breast cancer } \\
\text { cells (SKBR3 and } \\
\text { MDA-MB-231). } \\
\text { LSCM,FACS, } \\
\text { MTT test }\end{array}$ & $\begin{array}{l}\text { Spherical cage of } 12 \mathrm{~nm} \text {, } \\
\text { stabilizing } 10 \text { molecules } \\
\text { of drug. } \\
\text { To solve: localization of } \\
\text { the drug. }\end{array}$ & $\begin{array}{l}\text { VT: cellular } \\
\text { internalization } \\
\text { mediated by } \\
\text { interaction with } \\
\text { the TfR1 } \\
\text { receptor; } \\
\text { selective } \\
\text { antitumor } \\
\text { activity in } \\
\text { HER2 } \\
\text { overexpressing } \\
\text { cells. }\end{array}$ & $\begin{array}{l}{[42} \\
]\end{array}$ \\
\hline Doxorubicin & $\begin{array}{l}\text { Pre- } \\
\text { complexation } \\
\text { with } \mathrm{Cu} \text { and } \\
\text { incubation } \\
\text { with intact } \\
\text { APO }\end{array}$ & RGD & $\begin{array}{l}\text { Recombinan } \\
\mathrm{t} \\
\text { (bacterial) }\end{array}$ & $\begin{array}{l}\text { AFM, DLS, gel } \\
\text { filtration } \\
\text { chromatography } \\
\text {, Fluorescence } \\
\text { spectrometry }\end{array}$ & $\begin{array}{l}\text { VT: Human } \\
\text { glioblstoma cell } \\
\text { line (U87MG). } \\
\text { CLFM, MTT test } \\
\mathbf{V V : ~ W T ~ a n d ~ m i c e ~} \\
\text { bearing U87MG } \\
\text { cells. } \\
\text { Pharmacokinetics } \\
\text {; tissue } \\
\text { distribution; } \\
\text { histology; tumor } \\
\text { volume }\end{array}$ & $\begin{array}{l}\text { Cage of } 18.7 \mathrm{~nm} \text { with a } \\
\text { loading efficiency of } \\
73 \% \\
\text { To solve: localization of } \\
\text { the drug. }\end{array}$ & $\begin{array}{l}\text { VT: cellular } \\
\text { internalization } \\
\text { and } \\
\text { cytotoxicity } \\
\text { concentration } \\
\text { dependent. } \\
\text { VV: increased } \\
\mathrm{T}(1 / 2) \text { with } \\
\text { respect to free } \\
\text { drug. } \\
\text { Accumulation } \\
\text { into tumor } \\
\text { tissue mediated }\end{array}$ & $\begin{array}{l}{[45} \\
]\end{array}$ \\
\hline
\end{tabular}




\begin{tabular}{|c|c|c|c|c|c|c|c|}
\hline & & & & & $\checkmark$ & $\begin{array}{l}\text { by RGD- } \\
\text { integrin } \\
\text { interaction. } \\
\text { Tumor growth } \\
\text { inhibition } \\
\text { respect controls } \\
\text { (APO Vs saline } \\
\text { or free dug). }\end{array}$ & \\
\hline Doxorubicin & $\begin{array}{l}\text { Disassembly } \\
\text { in glycin } \\
\text { buffer(pH } \\
2.5) \text { followed } \\
\text { by reassembly } \\
\text { at } \\
\text { physiological } \\
\text { pH }\end{array}$ & Horse spleen & $\begin{array}{l}\text { gel } \\
\text { electrophoreses, } \\
\text { Fluorescence } \\
\text { spectrometry }\end{array}$ & & $\begin{array}{l}\text { Drug loading of } 23 \\
\text { molecules of drug. } \\
\text { To solve: structural } \\
\text { conformation }\end{array}$ & & $\begin{array}{l}{[48} \\
]\end{array}$ \\
\hline Doxorubicin & $\begin{array}{l}\text { Disassembly } \\
\text { at } \mathrm{pH} 2 \\
\text { followed by } \\
\text { reassembly at } \\
\text { physiological } \\
\text { pH }\end{array}$ & $\begin{array}{l}\text { Recombinan } \\
\text { t (H-Human) }\end{array}$ & $\begin{array}{l}\text { UV-VIS, gel } \\
\text { electrophoreses }\end{array}$ & $\begin{array}{l}\text { VT: human colon } \\
\text { adenocarcinoma } \\
\text { cell line (Caco-2), } \\
\text { human liver } \\
\text { carcinoma cell } \\
\text { line (HepG2). }\end{array}$ & & $\begin{array}{l}\text { VT: Rapid } \\
\text { cellular uptake } \\
\text { and nuclear } \\
\text { translocation of } \\
\text { loaded APO }\end{array}$ & $\begin{array}{l}{[50} \\
]\end{array}$ \\
\hline & & & & $L S C M$ and $W B$ & & & \\
\hline Doxorubicin & $\begin{array}{l}\text { Disassembly } \\
\text { at acidic pH } \\
\text { followed by } \\
\text { reassembly at } \\
\text { physiological } \\
\text { pH }\end{array}$ & $\begin{array}{l}\text { Recombinan } \\
\text { (H-Human) }\end{array}$ & $\begin{array}{l}\text { Fluorescence } \\
\text { spectrometry }\end{array}$ & $\begin{array}{l}\text { VT: Hela cells } \\
\text { and breast cancer } \\
\text { cells (MDA } \\
\text { MB468). }\end{array}$ & $\begin{array}{l}\text { Cage stabilizing } 28 \\
\text { molecules of drug; long } \\
\text { term controlled of drug } \\
\text { release (up to } 72 \text { h) in } \\
\text { PBS pH } 7 . \\
\text { To solve: structural }\end{array}$ & $\begin{array}{l}\text { VT: Rapid } \\
\text { cellular } \\
\text { internalization } \\
\text { and } \\
\text { cytotoxicity } \\
\text { (Apo Vs free } \\
\text { dug) }\end{array}$ & $\begin{array}{l}{[51} \\
]\end{array}$ \\
\hline
\end{tabular}




\begin{tabular}{|c|c|c|c|c|c|c|c|}
\hline & & & & $L S C M, M T T$ & conformation & & \\
\hline Doxorubicin & $\begin{array}{l}\text { Disassembly } \\
\text { in urea buffer } \\
\text { followed by } \\
\text { reassembly at } \\
\text { physiological } \\
\text { pH }\end{array}$ & $\begin{array}{l}\text { Recombinan } \\
\mathrm{t} \\
\text { (bacterial) }\end{array}$ & $\begin{array}{l}\text { TEM, DLS, } \\
\text { UV-VIS, } \\
\text { HPLC-UV. }\end{array}$ & $\begin{array}{l}\text { VT: human colon } \\
\text { cancer cell line } \\
\text { (HT-29). } \\
\text { CLFM. } \\
\text { VV: mice bearing } \\
\text { tumor cells (HT- } \\
29 \text { or A375 or } \\
\text { MDA-MB-231). } \\
\text { Pharmacokinetics } \\
\text { tumor volume }\end{array}$ & $\begin{array}{l}\text { Spherical cage of } 14 \mathrm{~nm} \text {, } \\
\text { stabilizing } 33 \text { molecules } \\
\text { of drug. } \\
\text { pH-dependent drug } \\
\text { release. } \\
\\
\text { To solve: structural } \\
\text { conformation }\end{array}$ & $\begin{array}{l}\text { VT: cellular } \\
\text { internalization } \\
\text { and } \\
\text { accumulation } \\
\text { into lysosomes. } \\
\text { VV: Increased } \\
\text { plasma half- } \\
\text { life. } \\
\text { Preferential } \\
\text { accumulation } \\
\text { in tumor tissue } \\
\text { respect to } \\
\text { healthy one. } \\
\text { Tumor growth } \\
\text { inhibition. } \\
\text { (APO Vs free } \\
\text { drug or Doxil) }\end{array}$ & $\begin{array}{l}{[52} \\
]\end{array}$ \\
\hline $\begin{array}{l}\text { Doxorubicin } \\
\text { Atropine } \\
\text { Carbachol }\end{array}$ & $\begin{array}{l}\text { Disassembly } \\
\text { in urea buffer } \\
\text { followed by } \\
\text { reassembly at } \\
\text { physiological } \\
\text { pH }\end{array}$ & Not reported & $\begin{array}{l}\text { TEM, DLS, } \\
\text { UV-VIS, } \\
\text { HPLC-UV }\end{array}$ & $\begin{array}{l}\text { VT: pancreatic } \\
\text { cancer cells } \\
\text { (PANC-1). } \\
\text { LCSM. } \\
\text { VV: WT and mice } \\
\text { bearing PANC-1. } \\
\text { Pharmacokinetics } \\
\text {; tumor volume }\end{array}$ & $\begin{array}{l}\text { Spherical cage of } 11 \mathrm{~nm} \text {, } \\
\text { stabilizing } 33 \text { (DOXO), } \\
47 \text { (Atropine) or } 58 \\
\text { (Carbacol) molecules of } \\
\text { drug. } \\
\text { pH-dependent drug } \\
\text { release. } \\
\text { To solve: structural } \\
\text { conformation }\end{array}$ & $\begin{array}{l}\text { VT : Rapid } \\
\text { accumulation } \\
\text { into tumoral } \\
\text { cell through } \\
\text { interaction with } \\
\text { TfR1 receptors. } \\
\text { VV: long term } \\
\text { circulation. } \\
\text { Accumulation }\end{array}$ & $\begin{array}{l}{[53} \\
]\end{array}$ \\
\hline
\end{tabular}




\begin{tabular}{|c|c|c|c|c|c|c|c|c|}
\hline & & & & & & & $\begin{array}{l}\text { into tumor site. } \\
\text { Reduction of } \\
\text { tumor volume } \\
\text { and increased } \\
\text { survival rate. } \\
\text { (loaded APO } \\
\text { Vs free drug) }\end{array}$ & \\
\hline $\begin{array}{l}\text { Daunomyci } \\
\mathrm{n}\end{array}$ & $\begin{array}{l}\text { Pre- } \\
\text { complexation } \\
\text { with PLLA. } \\
\text { Disassembly } \\
\text { at pH } 5 \\
\text { followed by } \\
\text { reassembly at } \\
\text { physiological } \\
\text { pH }\end{array}$ & & Not reported & $\begin{array}{l}\text { Fluorescence } \\
\text { spectroscopy }\end{array}$ & & $\begin{array}{l}\text { Increased drug } \\
\text { stabilization ( } 4 \text { times } \\
\text { higher) respect to non } \\
\text { complexed drug. } \\
\text { To solve: chemical and } \\
\text { structural } \\
\text { characterization. }\end{array}$ & & $\begin{array}{l}{[24} \\
]\end{array}$ \\
\hline $\begin{array}{l}\text { Daunomyci } \\
\mathrm{n}\end{array}$ & $\begin{array}{l}\text { Pre- } \\
\text { complexation } \\
\text { with PLLA. } \\
\text { Disassembly } \\
\text { at pH } 5 \\
\text { followed by } \\
\text { reassembly at } \\
\text { physiological } \\
\text { pH }\end{array}$ & HA & Not reported & $\begin{array}{l}\text { TEM, UV-VIS- } \\
\text { UV, FTIR, } \\
\text { Fluorescence } \\
\text { spectroscopy }\end{array}$ & $\begin{array}{l}\text { VT: Human lung } \\
\text { carcinoma cell } \\
\text { line (A549) and } \\
\text { human lung } \\
\text { fibroblast (MRC- } \\
\text { 5). } \\
\text { MTT, LCSM }\end{array}$ & $\begin{array}{l}\text { Spherical cage of } 28 \mathrm{~nm} \text {. } \\
\text { pH dependent drug } \\
\text { release. } \\
\text { To solve: localization of } \\
\text { the drug }\end{array}$ & $\begin{array}{l}\text { VT: Rapid } \\
\text { accumulation } \\
\text { into cancer cell } \\
\text { expressing } \\
\text { CD44 and } \\
\text { cytotoxicity } \\
\text { (APO Vs free } \\
\text { drug). }\end{array}$ & $\begin{array}{l}{[56} \\
]\end{array}$ \\
\hline $\begin{array}{l}\text { Cisplatin } \\
\text { Carboplatin } \\
\text { Oxaliplatin }\end{array}$ & $\begin{array}{l}\text { Disassembly } \\
\text { at } \mathrm{pH} 2 \\
\text { followed by } \\
\text { reassembly at } \\
\text { physiological } \\
\text { pH }\end{array}$ & & eported & $\begin{array}{l}\text { DLS, UV-VIS, } \\
\text { CD, ICP-MS }\end{array}$ & $\begin{array}{l}\text { VT: rat } \\
\text { pheochrocytoma } \\
\text { cell line (PC12). }\end{array}$ & $\begin{array}{l}\text { Spherical cage of } 13 \mathrm{~nm} \\
\text { encapsulating } 45 \\
\text { (cisplatin), } 17 \\
\text { (carboplatin), } 23 \\
\text { (oxaliplatin) molecule of } \\
\text { drug. }\end{array}$ & $\begin{array}{l}\text { VT: Increased } \\
\text { uptake and } \\
\text { cytotoxicity of } \\
\text { actives after } \\
\text { loading } \\
\text { (respect to free }\end{array}$ & $\begin{array}{l}{[35} \\
]\end{array}$ \\
\hline
\end{tabular}




\begin{tabular}{|c|c|c|c|c|c|c|c|c|}
\hline & & & & & $M T T, I C P-M S$ & $\begin{array}{l}\text { To solve: localization of } \\
\text { the drug }\end{array}$ & drug). & \\
\hline $\begin{array}{l}\text { Cisplatin } \\
\text { Carboplatin }\end{array}$ & $\begin{array}{l}\text { Disassembly } \\
\text { at } \mathrm{pH} 2 \\
\text { followed by } \\
\text { reassembly at } \\
\text { physiological } \\
\mathrm{pH} / \text { Passive } \\
\text { loading by pre } \\
\text { incubation } \\
\text { with } \mathrm{Pt}\end{array}$ & & Not reported & $\begin{array}{l}\text { TEM, UV-VIS, } \\
\text { NMR, ICP- } \\
\text { AES, gel } \\
\text { electrophoreses }\end{array}$ & $\begin{array}{l}\text { VT: rat } \\
\text { pheochrocytoma } \\
\text { cell line (PC12). } \\
\text { MTT }\end{array}$ & $\begin{array}{l}\text { Cage encapsulating } 15 \text { of } \\
\text { drug } \\
\text { To solve: localization of } \\
\text { the drug, structural } \\
\text { characterization }\end{array}$ & $\begin{array}{l}\text { VT: Decreased } \\
\text { viability of } \\
\text { cancer cells } \\
\text { (loaded Vs } \\
\text { unloaded APO) }\end{array}$ & $\begin{array}{l}{[46} \\
]\end{array}$ \\
\hline Cisplatin & $\begin{array}{l}\text { Disassembly } \\
\text { at pH } 13 \\
\text { followed by } \\
\text { reassembly at } \\
\text { physiological } \\
\text { pH }\end{array}$ & & Pig pancreas & $\begin{array}{l}\text { TEM, UV-VIS } \\
\text { CD, ICP-MS. }\end{array}$ & $\begin{array}{l}\text { VT: gastric cancer } \\
\text { cells (BGC } 823) \\
\text { and Hela. } \\
F A C S, M A L D I- \\
T O F / T O F, R T- \\
P C R \text {. }\end{array}$ & $\begin{array}{l}\text { Spherical cage } \\
\text { encapsulating } 12 \\
\text { Molecules of drug. } \\
\text { To solve: localization of } \\
\text { the drug }\end{array}$ & $\begin{array}{l}\text { VT: Induction } \\
\text { of apoptosis. }\end{array}$ & $\begin{array}{l}{[47} \\
]\end{array}$ \\
\hline Cisplatin & $\begin{array}{l}\text { Disassembly } \\
\text { at pH } 2 \\
\text { followed by } \\
\text { reassembly at } \\
\text { physiological } \\
\text { pH }\end{array}$ & $\begin{array}{l}\text { Antibod } \\
\text { y direct } \\
\text { to } \\
\text { CSPG4 }\end{array}$ & $\begin{array}{l}\text { Recombinan } \\
\mathrm{t} \\
\text { (H-bacterial) }\end{array}$ & $\begin{array}{l}\text { DLS, AUC, } \\
\text { SEC }\end{array}$ & $\begin{array}{l}\text { VT: melanoma } \\
\text { cell line } \\
\text { (CSPG4+) and } \\
\text { breast cancer cells } \\
\text { (CSPG4-). } \\
\text { Proliferation test } \\
\text { VV: CD1 nude } \\
\text { mice bearing } \\
\text { tumor. }\end{array}$ & $\begin{array}{l}\text { Protein cage of } 33 \mathrm{~nm} \\
\text { with a drug/protein } \\
\text { molar ratio of } 50 \\
\text { To solve: localization of } \\
\text { the drug, structural }\end{array}$ & $\begin{array}{l}\text { VT: increased } \\
\text { antiproliferativ } \\
\text { e effect } \\
\text { (modified Vs } \\
\text { not modified } \\
\text { APO). } \\
\text { VV: reduction } \\
\text { of tumor size in } \\
\text { mice bearing } \\
\text { melanoma. }\end{array}$ & $\begin{array}{l}{[57} \\
]\end{array}$ \\
\hline
\end{tabular}




\begin{tabular}{|c|c|c|c|c|c|c|c|c|}
\hline & & & & & $\begin{array}{l}\text { Evaluation of } \\
\text { tumor size }\end{array}$ & $\begin{array}{l}\text { characterization and } \\
\text { quantification of tigand }\end{array}$ & & \\
\hline $\begin{array}{l}\text { siRNA } \\
\text { (fluorescent } \\
\text { model } \\
\text { sequence) }\end{array}$ & $\begin{array}{l}\text { Incubation of } \\
\text { modified } \\
\text { APO with } \\
\text { siRNA }\end{array}$ & $\begin{array}{l}\text { CAP and } \\
\text { CTP }\end{array}$ & $\begin{array}{l}\text { Recombinan } \\
\mathrm{t} \\
\text { (H-Human) }\end{array}$ & $\begin{array}{l}\text { DLS, TEM, } \\
\text { polyacrylamide } \\
\text { gel }\end{array}$ & $\begin{array}{l}\text { VT: human breast } \\
\text { cancer cells } \\
\text { (MDA-MB-468) } \\
\text { and vimentin } \\
\text { expressing murine } \\
\text { melanoma } \\
\text { (B16F10). }\end{array}$ & $\begin{array}{l}\text { Complex of } 53 \mathrm{~nm} \\
\text { stabilizing siRNA } \\
\text { To solve: structural } \\
\text { characterization }\end{array}$ & $\begin{array}{l}\text { VT: Rapid } \\
\text { accumulation } \\
\text { into cytoplasm } \\
\text { of tumor cells }\end{array}$ & $\begin{array}{l}{[58} \\
]\end{array}$ \\
\hline
\end{tabular}

Table 1: APO utilization in drug delivery to cancer

LEGEND: AUC: analytical ultracentrifugation; CAP: Cationic peptides; CD: circular dichroism; CSPG4: Chondroitin sulfate proteoglycan 4; CTP: cell penetrating peptide; DLS: dynamic light scattering; FACS: fluorescence activated cells sorting; HA: Hyaluronic acid; HER2: Epidermal grown factor receptor 2; HPLC-UV: High-performance liquid chromatography- UV; ICP-EAS: Inductively coupled plasma atomic emission spectroscopy; ICP-MS: inductively coupled plasma mass spectrometer; LSCM: Laser-scanning Confocal Microscopy; MALDI TOF/TOF: Matrix-assisted laser desorption/ionization; MTT: 3-(4,5-dimetiltiazol-2-il)-2,5-difeniltetrazolio; NMR: Nuclear magnetic resonance; PLLA: poly-L-aspartic acid; RGD: peptide with affinity for integrin receptor upregulated on tumor endothelial cells; RT-PCR: Reverse transcriptase-polymerase chain reaction; SEC: size exclusion chromatography; TEM: transmission electron microscopy; TfR1: transferrin receptor; UV-FTIR: Fourier transform infrared spectroscopy; UV-VIS: Ultraviolet-visible spectroscopy; WB: western blot. 


\begin{tabular}{|c|c|c|c|c|c|c|c|c|}
\hline \multirow[b]{2}{*}{ Drug } & \multirow[b]{2}{*}{$\begin{array}{c}\text { Method of } \\
\text { encapsulatio } \\
\mathbf{n}\end{array}$} & \multirow[b]{2}{*}{$\begin{array}{c}\text { Surface } \\
\text { modificatio } \\
\mathbf{n}\end{array}$} & \multirow[b]{2}{*}{$\begin{array}{c}\text { Source of } \\
\text { APO }\end{array}$} & \multicolumn{5}{|c|}{ Outcomes/Short comings } \\
\hline & & & & $\begin{array}{l}\text { 1.Chemico- } \\
\text { physical and } \\
\text { technological } \\
\text { studies }\end{array}$ & $\begin{array}{l}\text { 2. In vitro (VT)/in } \\
\text { vivo (VV) model } \\
\text { test adopted }\end{array}$ & $\begin{array}{l}\text { Structural/technologic } \\
\text { al end point } \\
\text { Focus to solve }\end{array}$ & $\begin{array}{l}\text { Biological end } \\
\text { points }\end{array}$ & $\begin{array}{l}\text { RE } \\
\text { F }\end{array}$ \\
\hline $\begin{array}{l}\text { Gadoliniu } \\
\mathrm{m}\end{array}$ & $\begin{array}{l}\text { Passive } \\
\text { loading }\end{array}$ & & $\begin{array}{l}\text { Not } \\
\text { reported }\end{array}$ & $\begin{array}{l}\text { IR, TEM, UV- } \\
\text { Vis, ICP, SDS- } \\
\text { PAGE }\end{array}$ & & $\begin{array}{l}\text { Small cage stabilizing } \\
\text { GD (III); increase GD } \\
\text { longitudinal and } \\
\text { transverse relaxivities } \\
\text { To solve: structural } \\
\text { characterization; } \\
\text { localization of the drug. }\end{array}$ & & [61] \\
\hline $\begin{array}{l}\text { GD- } \\
\mathrm{Me}_{2} \mathrm{DO} 2 \mathrm{~A}\end{array}$ & $\begin{array}{l}\text { Disassembly } \\
\text { at } \mathrm{pH} 2 \\
\text { followed by } \\
\text { reassembly at } \\
\text { physiological } \\
\text { pH. Drug } \\
\text { was added } \\
\text { during the } \\
\text { basification } \\
\text { process. }\end{array}$ & dextran & $\begin{array}{l}\text { Not } \\
\text { reported }\end{array}$ & $\begin{array}{l}\text { TEM, UV-VIS, } \\
\text { ICP-EAS }\end{array}$ & $\begin{array}{l}\text { VV: mice bearing } \\
\text { HeLa cells. } \\
\text { MRI, NIRF }\end{array}$ & $\begin{array}{l}\text { Spherical } 30 \mathrm{~nm} \\
\text { modified cage } \\
\text { encapsulating } 36 \\
\text { molecules of contrast } \\
\text { agent. } \\
\text { To solve: structural } \\
\text { characterization; } \\
\text { localization of the drug. }\end{array}$ & $\begin{array}{l}\text { VV: massive } \\
\text { accumulation in } \\
\text { tumor site and } \\
\text { high proton } \\
\text { relaxivity. }\end{array}$ & {$[60]$} \\
\hline $\begin{array}{l}\text { GD- } \\
\text { HPDO3A }\end{array}$ & $\begin{array}{l}\text { Disassembly } \\
\text { at } \mathrm{pH} 2 \\
\text { followed by } \\
\text { reassembly at } \\
\text { physiological } \\
\text { pH }\end{array}$ & NCAM & $\begin{array}{l}\text { Not } \\
\text { reported }\end{array}$ & & $\begin{array}{l}\text { VT:renal cell } \\
\text { carcinoma cells } \\
\text { (TEC). } \\
I C P-M S, M R I \\
\text { VV: SCID mice } \\
\text { bearing TEC cells. } \\
\text { MRI, histology, }\end{array}$ & $\begin{array}{l}\text { Modified cage } \\
\text { encapsulating } 8-10 \\
\text { molecules of contrast } \\
\text { agent whit high } \\
\text { relaxivity ( } 5 \text { time } \\
\text { higher respect to free } \\
\text { molecule) }\end{array}$ & $\begin{array}{l}\text { VT: efficient } \\
\text { cellular } \\
\text { internalization } \\
\text { (loaded/modifie } \\
\text { d APO Vs } \\
\text { loaded APO) } \\
\text { VV: } \\
\text { accumulation }\end{array}$ & {$[62]$} \\
\hline
\end{tabular}




\begin{tabular}{|c|c|c|c|c|c|c|c|c|}
\hline & & & & & $\begin{array}{l}\text { immunofluorescenc } \\
\text { e. }\end{array}$ & $\begin{array}{l}\text { To solve: structural } \\
\text { characterization; } \\
\text { localization of the drug. }\end{array}$ & $\begin{array}{l}\text { into tumor site } \\
\text { (modified/loade } \\
\text { d APO }>\text { loaded } \\
\text { APO) }\end{array}$ & \\
\hline $\begin{array}{l}\text { GD- } \\
\text { HPDO3A }\end{array}$ & $\begin{array}{l}\text { Disassembly } \\
\text { at } \mathrm{pH} 2 \\
\text { followed by } \\
\text { reassembly at } \\
\text { physiological } \\
\text { pH }\end{array}$ & & $\begin{array}{l}\text { Not } \\
\text { reported }\end{array}$ & & & $\begin{array}{l}\text { Cage encapsulating } 10 \\
\text { molecules of contrast } \\
\text { agent. Relaxivity } \\
\text { constant for several } \\
\text { days. } \\
\text { To solve: structural } \\
\text { characterization; } \\
\text { localization of the drug. }\end{array}$ & & [59] \\
\hline $64 \mathrm{Cu}+\mathrm{Cy} 5$ & $\begin{array}{l}\text { Dissociation } \\
\text { at } \mathrm{pH} 2 \\
\text { followed by } \\
\text { reconstructio } \\
\mathrm{n} \text { at } \\
\text { physiological } \\
\mathrm{pH}\end{array}$ & RGD4C & $\begin{array}{l}\text { Not } \\
\text { reported }\end{array}$ & DLS , TEM & $\begin{array}{l}\text { VV: tumor bearing } \\
\text { U87MG glioma. } \\
\text { NIRF, PET, LCSM }\end{array}$ & $\begin{array}{l}\text { Absence of structural } \\
\text { analyses and } \\
\text { quantification of } \\
\text { exposed ligands }\end{array}$ & $\begin{array}{l}\text { VV: massive } \\
\text { tumor } \\
\text { accumulation } \\
\text { mediated by } \\
\text { RGD-integrin } \\
\text { interaction. }\end{array}$ & [78] \\
\hline $\mathrm{Fe} 3 \mathrm{O} 4$ & $\begin{array}{l}\text { Mineralizatio } \\
\mathrm{n} \text { procedure }\end{array}$ & None & $\begin{array}{l}\text { Recombina } \\
\text { nt (H- } \\
\text { Human) }\end{array}$ & $\begin{array}{l}\text { DLS, TEM, } \\
\text { MR. }\end{array}$ & $\begin{array}{l}\text { VT: murine } \\
\text { macrophage cells. } \\
M R, I C P-M S\end{array}$ & $\begin{array}{l}\text { Cage of } 12-13 \mathrm{~nm} \\
\text { encapsulating } 5000 \mathrm{Fe} . \\
\text { To solve: structural } \\
\text { characterization. }\end{array}$ & $\begin{array}{l}\text { VT: uptake of } \\
\text { Apo into cells } \\
\text { and } \\
\text { accumulation } \\
\text { of } 116 \mathrm{ug} \\
\mathrm{Fe} / \text { cell within } \\
72 \mathrm{~h}\end{array}$ & [72] \\
\hline $\mathrm{Fe} 3 \mathrm{O} 4$ & $\begin{array}{l}\text { Mineralizatio } \\
\mathrm{n} \text { procedure }\end{array}$ & RGD4G & $\begin{array}{l}\text { Recombina } \\
\text { nt (H- } \\
\text { Human) }\end{array}$ & $\begin{array}{l}\text { DLS, TEM, } \\
\text { magnetic } \\
\text { measurement }\end{array}$ & $\begin{array}{l}\text { VT: human } \\
\text { melanoma cell line } \\
\text { (C32). }\end{array}$ & $\begin{array}{l}\text { Spherical surface } \\
\text { modified cage of } 14 \mathrm{~nm} \\
\text { encapsulating } 5000 \\
\text { molecules of } \mathrm{Fe}\end{array}$ & $\begin{array}{l}\text { VT: specific } \\
\text { cellular uptake } \\
\text { mediated by } \\
\text { interaction with } \\
\text { integrin. }\end{array}$ & [73] \\
\hline
\end{tabular}




\begin{tabular}{|c|c|c|c|c|c|c|c|c|}
\hline & & & & & $F A C S, T E M$ & & & \\
\hline $\mathrm{Fe} 3 \mathrm{O} 4$ & $\begin{array}{l}\text { Mineralizatio } \\
\mathrm{n} \text { procedure }\end{array}$ & RGD & $\begin{array}{l}\text { Recombina } \\
\text { nt } \\
\text { (H-Human) }\end{array}$ & & $\begin{array}{l}\text { VT: bovine aortic } \\
\text { endothelial cells. } \\
\text { Fluorescence } \\
\text { microscopy } \\
\text { VV:WT mice. } \\
\text { Fluorescence } \\
\text { microscopy, } \\
\text { histology }\end{array}$ & & $\begin{array}{l}\text { VT: Enhanced } \\
\text { cellular uptake } \\
\text { (modified vs } \\
\text { not modified } \\
\text { APO) } \\
\text { VV: High } \\
\text { accumulation in } \\
\text { carotid arteries } \\
\text { (modified vs } \\
\text { not modified } \\
\text { APO) }\end{array}$ & [74] \\
\hline $\mathrm{Fe} 3 \mathrm{O} 4$ & $\begin{array}{l}\text { Mineralizatio } \\
\mathrm{n} \text { procedure }\end{array}$ & $\begin{array}{l}\text { EGF (ligand } \\
\text { for EGFR) }\end{array}$ & $\begin{array}{l}\text { Recombina } \\
\text { nt } \\
\text { (H-Human) }\end{array}$ & DLS, TEM. & $\begin{array}{l}\text { VT: breast } \\
\text { epithelial cells } \\
\text { (MCF-10A cells), } \\
\text { breast cancer cells } \\
\text { (MCF-7). } \\
\text { FACS, MTT } \\
\text { VV: nude mice } \\
\text { bearing MDA.MB- } \\
231 \text { tumor cells. } \\
\text { Weight and tumor } \\
\text { size, fluorescence } \\
\text { microscopy }\end{array}$ & 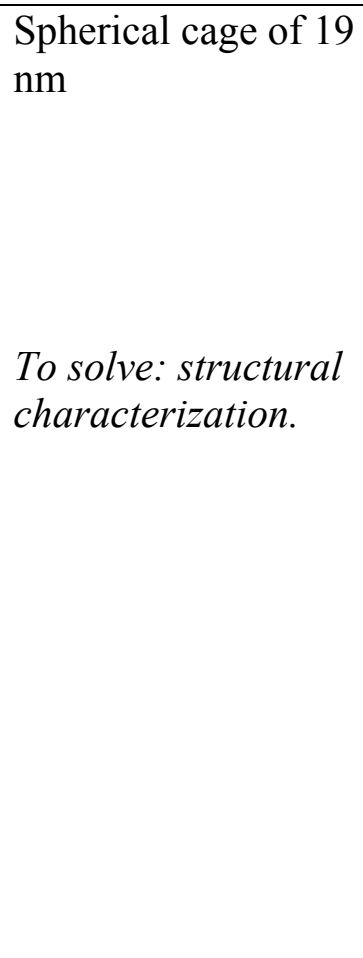 & $\begin{array}{l}\text { VT: absence of } \\
\text { toxicity at high } \\
\text { APO } \\
\text { concentration. } \\
\text { Good targeting } \\
\text { through cancer } \\
\text { cell respect to } \\
\text { normal cells } \\
\text { (interaction } \\
\text { with EGFR) } \\
\text { VV: no } \\
\text { influence in } \\
\text { body weight } \\
\text { and tumor size } \\
\text { (modified/loade } \\
\text { d APO Vs } \\
\text { saline). } \\
\text { Accumulation } \\
\text { into tumor } \\
\text { tissue. }\end{array}$ & [76] \\
\hline
\end{tabular}




\begin{tabular}{|c|c|c|c|c|c|c|c|c|}
\hline $\mathrm{Mn}$ & $\begin{array}{l}\text { Incubation } \\
\text { with } \mathrm{MnCl}_{2} \\
\text { at } \mathrm{pH} 9 \\
\text { followed by } \\
\text { reduction }\end{array}$ & None & $\begin{array}{l}\text { Horse } \\
\text { spleen }\end{array}$ & $\begin{array}{l}\text { TEM, UV-VIS, } \\
\text { size exclusion } \\
\text { chromatograph } \\
\text { y, NMR }\end{array}$ & & $\begin{array}{l}\text { Protein shell with a } \\
\text { mineral core. } \\
\text { Encapsulation of about } \\
1090 \text { Mn atoms. } \\
\text { To solve: structural } \\
\text { characterization and } \\
\text { localization of the } \\
\text { contrast agent }\end{array}$ & & {$[63]$} \\
\hline $\mathrm{Mn}$ & $\begin{array}{l}\text { Incubation } \\
\text { with } \mathrm{MnCl}_{2} \\
\text { at } \mathrm{pH} 9 \\
\text { followed by } \\
\text { reduction }\end{array}$ & None & $\begin{array}{l}\text { Horse } \\
\text { spleen and } \\
\text { recombinan } \\
\text { t }(\mathrm{H} \text { and } \mathrm{L} \\
\text { Human) }\end{array}$ & $\begin{array}{l}\text { TEM, UV-VIS, } \\
\text { EDXA }\end{array}$ & & $\begin{array}{l}\text { Protein shell } \\
\text { encapsulating mineral } \\
\text { core } \\
\text { To solve: structural } \\
\text { characterization. }\end{array}$ & & {$[64]$} \\
\hline $\mathrm{Mn}$ & $\begin{array}{l}\text { Incubation } \\
\text { with } \mathrm{MnCl}_{2} \\
\text { at } \mathrm{pH} 9 \\
\text { followed by } \\
\text { reduction }\end{array}$ & None & $\begin{array}{l}\text { Horse } \\
\text { spleen }\end{array}$ & $\begin{array}{l}\text { ICP-MS, } \\
\text { Bradford } \\
\text { quantification }\end{array}$ & $\begin{array}{l}\text { VT: HTC and } \\
\text { hepatocytes } \\
\text { ICP-MS } \\
\text { VV: WT and HBV- } \\
\text { Tg mice } \\
\text { Biodistribuition, } \\
\text { MRI }\end{array}$ & $\begin{array}{l}\text { Protein structure } \\
\text { encapsulating } 3000 \\
\text { Mn(II) ions } \\
\text { To solve: structural } \\
\text { conformation }\end{array}$ & $\begin{array}{l}\text { VT: high } \\
\text { accumulation in } \\
\text { healthy cells } \\
\text { respect to } \\
\text { hepatoma } \\
\text { VV: detection } \\
\text { of tumor lesion } \\
\text { and improved } \\
\text { sensitivity } \\
\text { respect to } \\
\text { commercial } \\
\text { probe for MRI }\end{array}$ & {$[65]$} \\
\hline $\mathrm{Mn}$ & $\begin{array}{l}\text { Incubation } \\
\text { with } \mathrm{MnCl}_{2} \\
\text { at pH } 9\end{array}$ & None & $\begin{array}{l}\text { Not } \\
\text { reported }\end{array}$ & UV-VIS, NMR & $\begin{array}{l}\text { VT: melanogenic } \\
\text { cells (B16-F10m) } \\
\text { and non }\end{array}$ & & $\begin{array}{l}\text { VT: } \\
\text { discrimination } \\
\text { between }\end{array}$ & {$[66]$} \\
\hline
\end{tabular}




\begin{tabular}{|l|l|l|l|l|}
\hline $\begin{array}{l}\text { followed by } \\
\text { reduction }\end{array}$ & & $\begin{array}{l}\text { melanogenic cells } \\
\text { (B16-F10non-m) } \\
\text { UV-VIS; ICP-MS } \\
\mathbf{V V} \text { : mouse } \\
\text { xenograft model } \\
\text { bearing B16-F10m } \\
M R\end{array}$ \\
VV: APO \\
accumulation \\
into tumor site
\end{tabular}

\section{Table 2: APO utilization in diagnosis}

LEGEND: EDXA: Energy Dispersive X-ray Analysis; LSCM: Laser-scanning Confocal Microscopy; ICP-MS: Inductively coupled plasma mass spectrometry; NMR: nuclear magnetic resonance; MR: magnetic resonance; NCAM: neural cell adhesion molecule; NIRF: near infrared fluorescence; PET: positron emission tomography; IR: Infrared spectroscopy; TEM: transmission electron microscopy; UV-VIS: Ultraviolet-visible spectroscopy; SDS-PAGE: Sodium Dodecyl Sulphate - PolyAcrylamide Gel Electrophoresis; ICP-EAS: Inductively coupled plasma atomic emission spectroscopy; DLS: : dynamic light scattering; MRI: Magnetic resonance imaging; ICP-MS: inductively coupled plasma mass spectrometer; PET: Positron Emission Tomography; MTT: 3-(4,5-dimetiltiazol-2-il)-2,5-difeniltetrazolio; FACS: fluorescence activated cells sorting; RGD: Arginylglycylaspartic acid; EGF: Epidermal growth factor; 


\begin{tabular}{|c|c|c|c|c|c|c|c|c|}
\hline \multirow[b]{2}{*}{ Drug } & \multirow[b]{2}{*}{$\begin{array}{l}\text { Method of } \\
\text { encapsulation }\end{array}$} & \multirow[b]{2}{*}{$\begin{array}{c}\text { Surface } \\
\text { modification }\end{array}$} & \multirow[b]{2}{*}{$\begin{array}{l}\text { Source } \\
\text { of APO }\end{array}$} & \multicolumn{5}{|c|}{ Outcomes/Short comings } \\
\hline & & & & $\begin{array}{l}\text { 1.Chemico- } \\
\text { physical and } \\
\text { technological } \\
\text { studies }\end{array}$ & $\begin{array}{l}\text { 2. In vitro } \\
\text { (VT)/in vivo } \\
\text { (VV) model } \\
\text { test adopted }\end{array}$ & $\begin{array}{l}\text { Structural/technological } \\
\text { end point }\end{array}$ & $\begin{array}{l}\text { Biological end } \\
\text { points }\end{array}$ & REF \\
\hline $\begin{array}{l}\text { Curcumin }+ \\
\text { Gd- } \\
\text { HPDO3A }\end{array}$ & $\begin{array}{l}\text { Disassembly } \\
\text { at } \mathrm{pH} 2 \\
\text { followed by } \\
\text { reassembly at } \\
\text { physiological } \\
\text { pH. }\end{array}$ & & $\begin{array}{l}\text { Horse } \\
\text { spleen }\end{array}$ & $\begin{array}{l}\text { SEC, UV- } \\
\text { VIS, ICP-MS }\end{array}$ & $\begin{array}{l}\text { VV: male mice } \\
\text { (C57BL), mice } \\
\text { model of liver } \\
\text { injury. }\end{array}$ & $\begin{array}{l}\text { Protein cage of } 19 \mathrm{~nm} \\
\text { encapsulating } 9.5 \text { and } 0.4 \\
\text { molecules of curcumin } \\
\text { and Gd-HPDO3A } \\
\text { respectively. Ability to } \\
\text { protect drug from } \\
\text { degradation. } \\
\text { To solve: structural } \\
\text { characterization }\end{array}$ & $\begin{array}{l}\text { VV: preferential } \\
\text { uptake by the liver } \\
\text { (about } 19 \% \text { of } \\
\text { injected dose). } \\
\text { Reduction of ALT, } \\
\text { leucocyte } \\
\text { infiltration and } \\
\text { hepatocyte } \\
\text { apoptosis levels. } \\
\text { (loaded Vs native } \\
\text { APO). }\end{array}$ & [83] \\
\hline $\begin{array}{l}\text { AU-NP and } \\
5-F U\end{array}$ & $\begin{array}{l}\text { Syntheses of } \\
\text { AU-NPs } \\
\text { inside the } \\
\text { protein cage } \\
\text { (AU } \\
\text { reduction) } \\
\text { followed by a } \\
\text { passive } \\
\text { loading of 5- } \\
\text { FU }\end{array}$ & & $\begin{array}{l}\text { Not } \\
\text { reported }\end{array}$ & $\begin{array}{l}\text { TEM, } \\
\text { EDXA, } \\
\text { PAGE, , CD, } \\
\text { UV-VIS, }{ }^{19} \text { F- } \\
\text { NMR. }\end{array}$ & $\begin{array}{l}\text { VT: non cancer } \\
\text { cells (HKC); } \\
\text { cancer cells } \\
\text { (HeLa , HepG2, } \\
\text { Caco-2, human } \\
\text { hepatic L02). } \\
\\
C C K-8, C L S M \text {, } \\
T E M, I C P-M S, \\
F A C S, B r d U, \\
W B\end{array}$ & $\begin{array}{l}\text { Regular protein cage } \\
\text { encapsulation } 45 \\
\text { molecules of drug. } \mathrm{pH} \\
\text { dependent drug release } \\
\text { To solve: localization of } \\
\text { the drug }\end{array}$ & $\begin{array}{l}\text { VT: Accumulation } \\
\text { of APO into } \\
\text { lysosomes; low } \\
\text { toxicity in control } \\
\text { cells; decreasing of } \\
\text { IC50 value ( } 15 \\
\text { times Vs free drug) } \\
\text { and increase of the } \\
\text { antiproliferative } \\
\text { effect in cancer } \\
\text { cells. }\end{array}$ & [84] \\
\hline Doxorubicin & $\begin{array}{l}\text { Disassembly } \\
\text { at } \mathrm{pH} 2\end{array}$ & $\begin{array}{l}\text { Magnetic } \\
\text { nanoparticles }\end{array}$ & $\begin{array}{l}\text { Not } \\
\text { reported }\end{array}$ & $\begin{array}{l}\text { Fluorimetric } \\
\text { analysis, CE }\end{array}$ & & $\begin{array}{l}\text { Partial encapsulation of } \\
\text { drug into protein cage }\end{array}$ & & [54] \\
\hline
\end{tabular}




\begin{tabular}{|c|c|c|c|c|c|c|c|c|}
\hline & $\begin{array}{l}\text { followed by } \\
\text { reassembly at } \\
\text { physiological } \\
\text { pH }\end{array}$ & & & & & $\begin{array}{l}\text { and } \mathrm{pH} \text { triggered drug } \\
\text { release. } \\
\text { To solve: structural } \\
\text { characterization; } \\
\text { localization of the drug }\end{array}$ & & \\
\hline Doxorubicin & $\begin{array}{l}\text { Disassembly } \\
\text { at pH } 2 \\
\text { followed by } \\
\text { reassembly at } \\
\text { physiological } \\
\text { pH }\end{array}$ & $\begin{array}{l}\text { HWR } \\
\text { peptide and } \\
\text { anti PSMA } \\
\text { antibodies; } \\
\text { AU-NP }\end{array}$ & $\begin{array}{l}\text { Horse } \\
\text { spleeen }\end{array}$ & $\begin{array}{l}\text { DLS, FT-IR, } \\
\text { PAGE, ICP- } \\
\text { MS }\end{array}$ & $\begin{array}{l}\text { VT: Human } \\
\text { umbilical vein } \\
\text { endothelial cells } \\
\text { (HUVEC), } \\
\text { human prostate } \\
\text { adenocarcinoma } \\
\text { cells (LNCCaP). }\end{array}$ & $\begin{array}{l}\text { Complex protein cage of } \\
22 \mathrm{~nm}, \mathrm{pH} \text { dependent } \\
\text { drug release. }\end{array}$ & $\begin{array}{l}\text { VT: specific } \\
\text { uptake in tumoral } \\
\text { cells and time } \\
\text { dependent } \\
\text { inhibition of cell } \\
\text { growth. } \\
\text { Excellent } \\
\text { hemocompatibility. }\end{array}$ & [81] \\
\hline
\end{tabular}

\section{Table 3: APO utilization in theranostic applications}

LEGEND: AU-NPs: gold nanoparticles; BrdU: Bromodeoxyuridine; CCK-8:cell counting kit; CD= circular dichroism; CE: Capillary electrophoreses; CLSM: confocal laser scanning microscopy; DLS. dynamic light scattering; EDXA: energy dispersive X-ray analysis; FACS: fluorescence activated cells sorting; FACS: fluorescence activated cells sorting; FT-IR: Fourier transform infrared spectroscopy; ICP-MS: inductively coupled plasma mass spectrometer; MR: magnetic resonance; NMR: nuclear magnetic resonance; PMSA: prostate specific membrane antigen; SEC: size exclusion chromatography; TEM: transmission electron microscopy; UV-VIS: Ultraviolet-visible spectroscopy; WB: western blot: 5-FU: 5-Fluorouraciil. 


\begin{tabular}{|c|c|c|c|c|c|c|c|c|}
\hline \multirow[b]{2}{*}{ Drug } & \multirow[b]{2}{*}{$\begin{array}{c}\text { Method of } \\
\text { encapsulation }\end{array}$} & \multirow[b]{2}{*}{$\begin{array}{c}\text { Surface } \\
\text { modification }\end{array}$} & \multirow[b]{2}{*}{$\begin{array}{l}\text { Source of } \\
\text { APO }\end{array}$} & \multicolumn{5}{|c|}{ Outcomes/Short comings } \\
\hline & & & & $\begin{array}{l}\text { 1.Chemico- } \\
\text { physical and } \\
\text { technological } \\
\text { studies }\end{array}$ & $\begin{array}{l}\text {. In } \\
\text { vitro/in } \\
\text { vivo test }\end{array}$ & $\begin{array}{l}\text { Structural/technological } \\
\text { end point }\end{array}$ & Biological end points & REF \\
\hline & & $\begin{array}{l}\text { OT-1 and } \\
\text { OT-2 }\end{array}$ & $\begin{array}{l}\text { Recombinant } \\
\text { (bacterial) }\end{array}$ & $\begin{array}{l}\text { DLS, TEM, } \\
\text { MS }\end{array}$ & $\begin{array}{l}\text { VT: } \\
\text { splenocyte } \\
\text { from } \\
\text { C57BL/6 } \\
\text { mice. } \\
\text { FACS } \\
\text { VV: } \\
\text { C57BL/6 }\end{array}$ & $\begin{array}{l}\text { Spherical cage of } 13 \mathrm{~nm} \\
\text { exposing antigen in the } \\
\text { inner or outer surface. } \\
\text { To solve: structural } \\
\text { characterization }\end{array}$ & $\begin{array}{l}\text { VT: increased of T cell } \\
\text { proliferation after APO } \\
\text { exposure. } \\
\text { VV: effective } \\
\text { differentiation of } \\
\text { activated T cells in } \\
\text { functional effector T } \\
\text { cells }\end{array}$ & {$[85]$} \\
\hline & $\begin{array}{l}\text { Incubation of } \\
\text { recombinant } \\
\text { protein in } \\
\text { TRIS buffer at } \\
\text { physiologic } \\
\text { pH and } \\
\text { purification }\end{array}$ & HA & $\begin{array}{l}\text { Recombinant } \\
\text { (bacterial) }\end{array}$ & $\begin{array}{l}\text { DLS, TEM, } \\
\text { SEC. }\end{array}$ & $\begin{array}{l}\text { VV: } \\
\text { female } \\
\text { BALB/c } \\
\text { mice }\end{array}$ & $\begin{array}{l}\text { Smooth spherical cage } \\
\text { exposing antigens } \\
\text { To solve: structural } \\
\text { characterization }\end{array}$ & $\begin{array}{l}\mathbf{V V} \text { : inhibition of } \\
\text { hemoagglutination }\end{array}$ & {$[86]$} \\
\hline $\begin{array}{l}\text { glucose } \\
\text { oxidase }\end{array}$ & $\begin{array}{l}\text { Surface } \\
\text { attachment } \\
\text { through } \\
\text { biotin- } \\
\text { streptavidin } \\
\text { technology }\end{array}$ & & ot reported & $\begin{array}{l}\text { TEM, UV- } \\
\text { VIS }\end{array}$ & & $\begin{array}{l}\text { Cage of } 16 \mathrm{~nm} \text { with an } \\
\text { irregular morphology and } \\
\text { largely aggregated } \\
\text { stabilizing } 8 \text { molecules of } \\
\text { enzyme. } \\
\text { To solve: structural } \\
\text { characterization }\end{array}$ & & {$[50]$} \\
\hline
\end{tabular}


Table 4: APO utilization in therapy

LEGEND: DLS: dynamic light scattering; FACS: fluorescence activated cells sorting; HA: Influenza virus hemagglutinin; MS: mass spectrometry; OT1/OT": Antigen peptides derived from ovalbumin; SEC: size exclusion chromatography; TEM: transmission electron microscopy; UV-VIS:

Ultraviolet-visible spectroscopy; 


\begin{tabular}{|c|c|c|c|c|}
\hline & Category & Drug & Note & Ref \\
\hline Anticancer & $\begin{array}{l}\text { Tyrosine kinase } \\
\text { inhibitor }\end{array}$ & Gefinitinib & 10 molecules/APO loading & 42 \\
\hline & Anthracyclin & Doxorubicin & $\begin{array}{l}\text {-pre-complexation with } \mathrm{Cu}^{2+} \\
\text { increase the drug loading }\end{array}$ & $43-45$ \\
\hline & Anthracyclin & Daunorubicin & $\begin{array}{l}\text {-acidic protocol } \\
\text {-surface conjugation for } \\
\text { targeting } \\
\text {-pre-complexation with } \\
\text { negatively charged peptides }\end{array}$ & \\
\hline & $\begin{array}{l}\text { Alkylating } \\
\text { agents }\end{array}$ & Cisplatin & $\begin{array}{l}\text {-strong acidic protocol } \\
-2 \text { molecules/APO }\end{array}$ & 46 \\
\hline & $\begin{array}{l}\text { Alkylating } \\
\text { agents }\end{array}$ & Carboplatin & -strong acidic protocol & 46 \\
\hline & $\begin{array}{l}\text { Alkylating } \\
\text { agents }\end{array}$ & Cisplatin & -alkaline protocol & 47 \\
\hline & $\begin{array}{l}\text { Alkylating } \\
\text { agents }\end{array}$ & Cisplatin & $\begin{array}{l}\text {-alkaline protocol } \\
\text {-surface modification }\end{array}$ & 34,57 \\
\hline & Antimuscarinic & Atropine & l & 53 \\
\hline & Cholinomimetic & Carbachol & / & 53 \\
\hline & & SiRNA & $\begin{array}{l}\text {-modification with protamine- } \\
\text { derived peptides for } \\
\text { complexation }\end{array}$ & 58 \\
\hline \multirow[t]{2}{*}{ Diagnostic } & & Gadolinium & $\begin{array}{l}\text {-acidic protocol } \\
\text {-neutral chelates }\end{array}$ & $59-62$ \\
\hline & & Gadolinium & $\begin{array}{l}\text {-neutral chelates } \\
\text {-surface modification for tumor } \\
\text { targeting }\end{array}$ & 62 \\
\hline
\end{tabular}




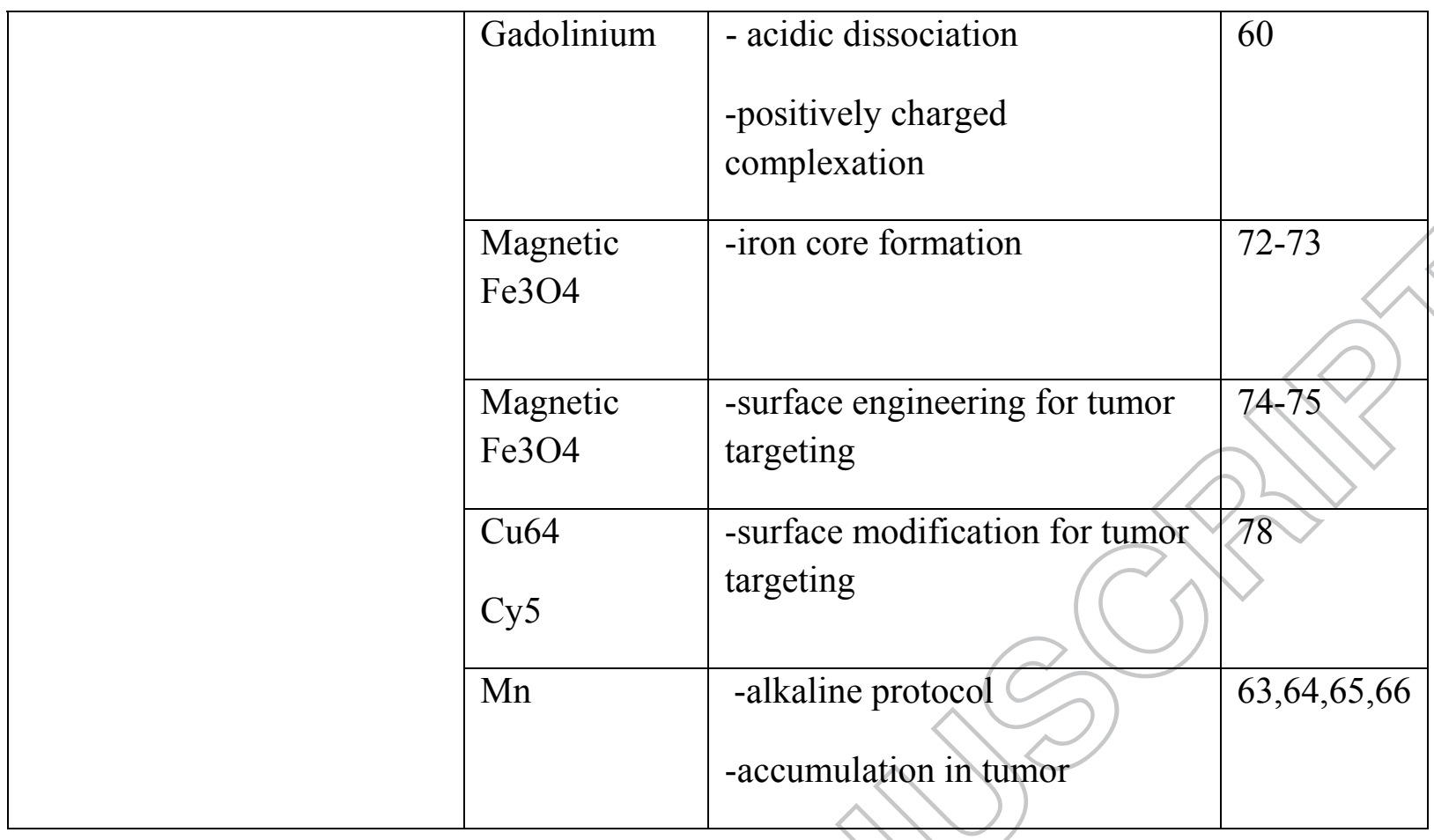

Table 5: Summary of molecules and active agents loaded into APO nanocages. 